\title{
Diversity of cultured photosynthetic flagellates in the northeast Pacific and Arctic Oceans in summer
}

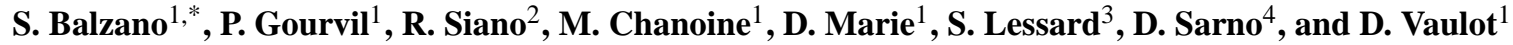 \\ ${ }^{1}$ CNRS et Université Pierre et Marie Curie (Paris-06), UMR7144, Station Biologique de Roscoff, 29680 Roscoff, France \\ ${ }^{2}$ IFREMER, centre de Brest, DYNECO, Pelagos, BP 70 29280, Plouzané, France \\ ${ }^{3}$ Institut des Sciences de la Mer, Rimouski, Québec, Canada \\ ${ }^{4}$ Taxonomy and Identification of Marine Phytoplankton, Stazione Zoologica Anton Dohrn, Villa Comunale, \\ 80121 Napoli, Italy \\ * present address: School of Biological Sciences, Flinders University, P.O. Box 2100, Adelaide, \\ South Australia 5001, Australia
}

Correspondence to: S. Balzano (sergio.balzano@flinders.edu.au)

Received: 5 May 2012 - Published in Biogeosciences Discuss.: 1 June 2012

Revised: 20 September 2012 - Accepted: 2 October 2012 - Published: 16 November 2012

\begin{abstract}
During the MALINA cruise (summer 2009), an extensive effort was undertaken to isolate phytoplankton strains from the northeast (NE) Pacific Ocean, the Bering Strait, the Chukchi Sea, and the Beaufort Sea. In order to characterise the main photosynthetic microorganisms occurring in the Arctic during the summer season, strains were isolated by flow cytometry sorting (FCS) and single cell pipetting before or after phytoplankton enrichment of seawater samples. Strains were isolated both onboard and back in the laboratory and cultured at $4{ }^{\circ} \mathrm{C}$ under light/dark conditions. Overall, we isolated and characterised by light microscopy and $18 \mathrm{~S}$ rRNA gene sequencing 104 strains of photosynthetic flagellates which grouped into 21 genotypes (defined by $99.5 \% 18 \mathrm{~S}$ rRNA gene sequence similarity), mainly affiliated to Chlorophyta and Heterokontophyta. The taxon most frequently isolated was an Arctic ecotype of the green algal genus Micromonas (Arctic Micromonas), which was nearly the only phytoplankter recovered within the picoplankton $(<2 \mu \mathrm{m})$ size range. Strains of Arctic Micromonas as well as other strains from the same class (Mamiellophyceae) were identified in further detail by sequencing the internal transcribed spacer (ITS) region of the rRNA operon. The MALINA Micromonas strains share identical $18 \mathrm{~S}$ rRNA and ITS sequences suggesting high genetic homogeneity within Arctic Micromonas. Three other Mamiellophyceae strains likely belong to a new genus. Other green algae from the genera Nephroselmis, Chlamydomonas,
\end{abstract}

and Pyramimonas were also isolated, whereas Heterokontophyta included some unidentified Pelagophyceae, Dictyochophyceae (Pedinellales), and Chrysophyceae (Dinobryon faculiferum). Moreover, we isolated some Cryptophyceae (Rhodomonas sp.) as well as a few Prymnesiophyceae and dinoflagellates. We identified the dinoflagellate Woloszynskia cincta by scanning electron microscopy (SEM) and $28 \mathrm{~S}$ rRNA gene sequencing. Our morphological analyses show that this species possess the diagnostic features of the genus Biecheleria, and the 28 S rRNA gene topology corroborates this affiliation. We thus propose the transfer of $W$. cincta to the genus Biecheleria and its recombination as Biecheleria cincta.

\section{Introduction}

Arctic phytoplankton undergoes a high seasonal variability with most of the biomass occurring during late summer (Sherr et al., 2003; Wang et al., 2005). During this period, freshwater inputs from rivers and ice melting in the Beaufort Sea lead to strong stratification of the water column. Consequently, phytoplankton depletes the surface layer of nutrients, especially inorganic nitrogen (Carmack and MacDonald, 2002). 
In the Canadian Arctic, diatoms tend to dominate near the coast (Lovejoy et al., 2002; Sukhanova et al., 2009) and flagellates prevail in offshore waters, especially in mid and late summer (Booth and Horner, 1997; Sherr et al., 2003). Arctic photosynthetic picoplankton is dominated by the green algal class Mamiellophyceae (Not et al., 2005; Lovejoy et al., 2007), specifically by a Micromonas ecotype (Arctic Micromonas) genetically and physiologically distinct from Micromonas genotypes typically found in warmer oceans (Slapeta et al., 2006; Lovejoy et al., 2007). This ecotype occurs in the Arctic throughout the year (Sherr et al., 2003), replacing cyanobacteria as the baseline community $(\mathrm{Li}$, 1998). In contrast, larger $(>2 \mu \mathrm{m})$ photosynthetic flagellates fluctuate during the year and are more diverse (Booth et al., 1982; Booth and Horner, 1997; Lovejoy et al., 2002).

The summer composition of photosynthetic pico- and nanoplankton has been investigated in great detail from the northeast (NE) Pacific to the Beaufort Sea during the MALINA cruise in summer 2009 (Balzano et al., 2012). Terminal restriction fragment length polymorphism (T-RFLP) and cloning/sequencing approaches have confirmed the ubiquity of Arctic Micromonas, which occurred in the NE Pacific, dominated the Bering Strait and was nearly the unique photosynthetic picoplankter found throughout the Beaufort Sea in both nitrogen-depleted surface waters and nitrogen-replete deep chlorophyll maximum (DCM) waters. It is not known whether such ubiquity and exclusivity covers intraspecific differences between populations occurring under different seawater conditions or whether populations are rather homogeneous and all adapted to variable conditions. In contrast, nanoplankton was more diverse and dominated by cultured microorganisms mainly belonging to diatoms, Chrysophyceae, and Pelagophyceae.

Despite obvious biases, culturing approaches permit a better characterisation of the strains isolated by the combination of microscopy and molecular methods (Le Gall et al., 2008). To date, existing datasets on Arctic phytoplankton are based either on light microscopy (Okolodkov and Dodge, 1996; Booth and Horner, 1997; Lovejoy et al., 2002; Sukhanova et al., 2009) or cloning/sequencing (Lovejoy et al., 2006; Luo et al., 2009; Lovejoy and Potvin, 2011), but few studies have performed large scale isolation efforts in the Arctic.

The present study aimed at the detailed characterisation of strains isolated during the MALINA cruise. One of our goals was to assess whether the main Arctic species are endemic or occur in other oceans. During the MALINA cruise, we isolated about 200 strains from the NE Pacific, the Bering Strait, the Chuckchi Sea, and the Beaufort Sea using different approaches (flow cytometry sorting, single cell pipetting). About half of the strains belonged to diatoms and will be investigated in a parallel study. Here, we characterise photosynthetic flagellates by $18 \mathrm{~S}$ rRNA gene sequencing. We also sequenced the internal transcribed spacer (ITS) region of the rRNA operon from our strains of Mamiellophyceae to assess whether Arctic Micromonas is genetically homogeneous or consists of several distinct genotypes, and if the other Mamiellophyceae strains isolated here correspond to a new genus. Finally, we characterised in further detail, by scanning electron microscopy (SEM) and $28 \mathrm{~S} \mathrm{rRNA}$ gene sequencing, two dinoflagellate strains belonging to Woloszynskia cincta, a recently described species (Siano et al., 2009), and propose a taxonomical revision of the species.

\section{Materials and methods}

\subsection{Sampling}

The MALINA cruise took place on board the Canadian research vessel CCGS Amundsen during the summer of 2009 from Victoria (British Columbia, Canada) to the Beaufort Sea (Table 1, leg 1b) and then throughout the Beaufort Sea (leg 2b). Seawater samples were collected with a bucket from the surface during leg $1 \mathrm{~b}$ and at different depths with Niskin bottles mounted on a CTD frame during leg 2 b. Water temperature, salinity, nutrient concentrations, and the phytoplankton composition were obtained from the MALINA database (http://www.obs-vlfr.fr/Malina/data. html).

\subsection{Strain isolation}

Phytoplankton strains were isolated both onboard and back in the laboratory. Onboard, strains were isolated on 5 $\mathrm{ml}$ glass tubes by flow cytometry sorting (FCS) either directly from the seawater, as well as from samples concentrated by tangential flow filtration (TFF) (Marie et al., 2010), or from enriched seawater samples. Samples were enriched by mixing $4.5 \mathrm{ml}$ of 2 fold diluted medium with $0.5 \mathrm{ml}$ of seawater in $5 \mathrm{ml}$ glass tubes and by incubating the tubes under light-dark conditions for at least three days prior to isolations. Media used for the enrichments included $\mathrm{f} / 2$ (Guillard, 1975), K (Keller et al., 1987), Jaworski (http://www.ccap.ac.uk/media/recipes/ JM.htm), Erd-Schreiber (Kasai et al., 2009), and PCR-S11 (Rippka et al., 2000). Seventeen medium enrichments were spiked with $9.6 \mu \mathrm{MGeO}_{2}$ (Sigma-Aldrich, Saint-Quentin, France) to prevent the growth of diatoms (Supplement, Table S1). All strains were maintained on a $12: 12$ light-dark cycle and transferred weekly to new medium. Samples and cultures from the surface were incubated under white light $\left(100 \mu\right.$ moles photons $\left.\mathrm{m}^{2} \mathrm{~s}^{-1}\right)$ while samples from deeper layers were incubated under blue light $(10 \mu$ moles photons $\mathrm{m}^{2} \mathrm{~s}^{-1}$ ).

One to six months after the MALINA cruise, more strains were isolated in the laboratory using single cell pipetting or FCS from TFF concentrated or enriched samples. Some strains were found to be non-unialgal or contaminated by small heterotrophs and were further purified using single-cell FCS (Supplement, Table S1). FCS was carried out using a 
Table 1. Sampling stations. The last five columns provide the number of flagellate cultures obtained using different isolation techniques.

\begin{tabular}{|c|c|c|c|c|c|c|c|c|}
\hline \multirow[t]{2}{*}{ Station } & \multirow[t]{2}{*}{$\begin{array}{r}\text { CTD } \\
(\mathrm{m})\end{array}$} & \multirow[t]{2}{*}{$\begin{array}{r}\text { Latitude } \\
\left({ }^{\circ} \mathrm{N}\right)\end{array}$} & \multirow[t]{2}{*}{$\begin{array}{r}\text { Longitude } \\
\left({ }^{\circ} \mathrm{W}\right)\end{array}$} & \multirow{2}{*}{$\begin{array}{r}\text { Cultures } \\
\text { direct } \\
\text { FCS }^{\mathrm{a}}\end{array}$} & \multicolumn{2}{|c|}{$\begin{array}{l}\text { Cultures } \\
\text { TFF }^{\mathrm{b}}\end{array}$} & \multicolumn{2}{|c|}{$\begin{array}{c}\text { Culture } \\
\text { enrichments }\end{array}$} \\
\hline & & & & & $\mathrm{FCS}^{\mathrm{a}}$ & $\mathrm{SCP}^{\mathrm{c}}$ & $\mathrm{FCS}^{\mathrm{a}}$ & $\mathrm{SCP}^{\mathrm{c}}$ \\
\hline PAC06 & & 50.06 & 139.53 & & & & 2 & \\
\hline PAC08 & & 53.36 & 159.29 & & & & & 1 \\
\hline BER09 & & 56.51 & 166.22 & & & & 2 & \\
\hline BER10 & & 62.14 & 167.54 & 1 & & & 3 & \\
\hline ARC11 & & 67.49 & 168.12 & & & & 2 & \\
\hline ARC12 & & 71.19 & 159.42 & 3 & & & 3 & \\
\hline BEA13 & & 70.56 & 145.40 & 3 & & & 4 & \\
\hline BEA14 & & 70.50 & 135.50 & 2 & & & 2 & \\
\hline 110 & 56 & 71.70 & 126.48 & & & 4 & & \\
\hline 235 & 191 & 71.76 & 130.83 & 3 & & 1 & & \\
\hline 280 & 42 & 70.87 & 130.51 & & 2 & 5 & & \\
\hline 320 & 82 & 71.57 & 133.94 & 4 & & & & \\
\hline 345 & 125 & 71.33 & 132.57 & 2 & & & & \\
\hline 394 & 38 & 69.85 & 133.50 & 1 & & 2 & & \\
\hline 430 & 138 & 71.22 & 136.72 & 2 & & & & \\
\hline 460 & 145 & 70.67 & 136.08 & 3 & & & & \\
\hline 540 & 134 & 70.75 & 137.89 & 1 & & & & \\
\hline 620 & 99 & 70.70 & 139.61 & 8 & 1 & 4 & & \\
\hline 670 & 89 & 69.80 & 138.44 & 2 & 1 & 2 & & \\
\hline 680 & 35 & 69.61 & 138.21 & & & 8 & & \\
\hline 690 & 31 & 69.49 & 137.94 & 1 & & 4 & & \\
\hline 760 & 106 & 70.55 & 140.80 & 12 & & 3 & & \\
\hline Total & & & & 48 & 4 & 33 & 18 & 1 \\
\hline
\end{tabular}

FACSAria (Becton Dickinson, San Jos'e, CA, USA) either on board or back in the laboratory. For each strain between 1 and 20000 cells were sorted either into 96 -well plates or directly into $5 \mathrm{ml}$ glass tubes prefilled with $\mathrm{K} / 2$ (Keller et al., 1987) medium. Different cell populations (picoeukaryotes, nanoeukaryotes, and microeukaryotes) were discriminated based on side scatter as well as orange and red fluorescence following excitation at $488 \mathrm{~nm}$ as described previously (Marie et al., 2010). Sorting was done in purity mode and samples were immediately transferred at $4{ }^{\circ} \mathrm{C}$.

For single cell pipette isolation, TFF concentrated or enriched seawater samples were observed using an inverted microscope Olympus IX71 (Olympus, Hamburg, Germany) and $1.5 \mathrm{ml}$ from each sample were collected and transferred into a 24-well Iwaki plate (Starlab, Bagnieux, France). A sample aliquot was transferred into a new well containing sterile medium and this step was repeated 4 times for a final 100000 fold dilution of the enriched sample. Single cells were then collected using a Nichipet EX $0.5-10 \mu \mathrm{l}$ (Starlab, Bagnieux, France), transferred again into new plates containing sterile media and incubated at $4{ }^{\circ} \mathrm{C}$ under light-dark conditions for 1 to 2 weeks.

\subsection{Molecular analyses}

Genomic DNA was extracted from 104 strains of photosynthetic flagellates: a volume of $2 \mathrm{ml}$ was collected from the cultures during the stationary-state growth phase, centrifuged at $11000 \mathrm{rpm}$ for $10 \mathrm{~min}$, and $1.8 \mathrm{ml}$ of supernatant removed. The genomic DNA was then extracted using Qiagen Blood and Tissue kit (Qiagen, Cortaboeuf, France) as described previously (Balzano et al., 2012).

For PCR, $1 \mu \mathrm{l}$ of genomic DNA was mixed with $0.5 \mu \mathrm{l}$ of $10 \mu \mathrm{M}$ solution of both forward and reverse primers, $15 \mu \mathrm{l}$ of HotStar Taq Plus Master Mix Kit (Qiagen, Courtaboeuf, France), $3 \mu$ l of Coral Load (Qiagen, Courtaboeuf, France), and Milli-Q water up to a final volume of $30 \mu \mathrm{l}$. For the $18 \mathrm{SrRNA}$ gene, primers 63f (5'-ACG-CTT-GTC-TCA-AAG-ATT-A-3') and $1818 \mathrm{r}$ (5'-ACG-GAA-ACC-TTG-TTA-CGA-3') were used (Lepére et al., 2011). PCR reactions were performed with an initial incubation step at $95^{\circ} \mathrm{C}$ during $5 \mathrm{~min}, 35$ amplification cycles $\left(95^{\circ} \mathrm{C}\right.$ for $1 \mathrm{~min}, 57^{\circ} \mathrm{C}$ for $1 \mathrm{~min} 30 \mathrm{~s}$, and $72^{\circ} \mathrm{C}$ for $1 \mathrm{~min}$ $30 \mathrm{~s}$ ) and a final elongation step at $72^{\circ} \mathrm{C}$ for $10 \mathrm{~min}$.

The ITS region of the rRNA operon was amplified from 28 Mamiellophyceae strains, most of them (24) 
belonging to Arctic Micromonas, using the universal primers ITS-1 (5'-TCC-GTA-GGT-GAA-CCT-GCG-G-3') and ITS-4 (5'-TCC-TCC-GCT-TAT-TGA-TAT-GC-3') which amplify very small portions of both $18 \mathrm{~S}$ and $28 \mathrm{~S}$ rRNA genes and the whole ITS region (White et al., 1990). PCR reactions were performed with an initial incubation step at $94^{\circ} \mathrm{C}$ for $2 \mathrm{~min}, 40$ amplification cycles $\left(94^{\circ} \mathrm{C}\right.$ for $35 \mathrm{~s}$, $46.2^{\circ} \mathrm{C}$ for $35 \mathrm{~s}$, and $72^{\circ} \mathrm{C}$ for $1 \mathrm{~min}$ ), and a final elongation step at $72^{\circ} \mathrm{C}$ for $10 \mathrm{~min}$.

For the two dinoflagellate strains RCC2013 and MALINA FT56.6 PG8, the 28 SrRNA gene was amplified using primers D1R ( $5^{\prime}$-ACC-CGC-TGA-ATT-TAA-GCA-TA-3') and D3Ca (5'-ACG-AAC-GAT-TTG-CAC-GTC-AG-3') targeting the D1-D3 region of the nuclear LSU rDNA (Lenaers et al., 1989). PCR reactions included: 30 amplification cycles of $94^{\circ} \mathrm{C}$ for $1 \mathrm{~min}, 55^{\circ} \mathrm{C}$ for $1 \mathrm{~min} 30 \mathrm{~s}$, and $72^{\circ} \mathrm{C}$ for $1 \mathrm{~min}$.

$18 \mathrm{~S}$ rRNA, ITS, and $28 \mathrm{~S}$ rRNA amplicons were purified using Exosap (USB products, Santa Clara, USA) and partial sequences were determined by using Big Dye Terminator V3.1 (Applied Biosystems, Foster city, USA). A highly variable region of the $18 \mathrm{SrRNA}$ gene was sequenced using the internal primer Euk528f (5'-CCG-CGG-TAATTC-CAG-CTC-3', Zhu et al., 2005). The ITS region and the $28 \mathrm{~S}$ rRNA gene were sequenced using the primers ITS-4 and D1R, respectively. Sequencing was carried out on a ABI prism 3100 sequencer (Applied Biosystems, Foster city, USA).

\subsection{Phylogenetic analyses}

Partial 18 SrRNA sequences were compared to those available in Genbank using BLAST (http://blast.ncbi.nlm. nih.gov//Blast.cgi) and attributed to different high level taxa. For each major taxonomic group (Chlorophyta, Cryptophyta, Alveolata, Heterokontophyta, Haptophyta), sequences were aligned using ClustalW2 (http://www.ebi.ac.uk/Tools/msa/ clustalw2) and then grouped into 21 genotypes based on 99.5\% sequence similarity using Bioedit software (Hall, 1999). We calculated a rarefaction curve using Ecosim (http: //www.garyentsminger.com/ecosim/index.htm) software to evaluate the portion of cultured phytoplankton diversity that we isolated during the leg $2 b$ of the MALINA cruise.

Based on this preliminary analysis, the full $18 \mathrm{~S}$ rRNA gene was sequenced for at least one strain per genotype using primers $63 \mathrm{f}$ and $1818 \mathrm{r}$, described above. Twenty-seven full $18 \mathrm{~S}$ rRNA sequences were aligned with environmental sequences from the MALINA cruise (Balzano et al., 2012) as well as with other reference sequences from Genbank (http: //www.ncbi.nlm.nih.gov/nucleotide), as described above. A total of 180 sequences were finally aligned. Highly variable regions of the alignment were manually removed. Phylogenetic relationships were analysed using maximum likelihood (ML) and neighbour joining (NJ) methods (Nei and Kumar, 2000). Different models of DNA substitutions and associated parameters were estimated on 1553 unambiguously aligned positions using MEGA5 (Tamura et al., 2011). A General Time Reversible (GTR) model with gamma distributed invariant sites $(\mathrm{G}+\mathrm{I})$ was then selected as the best model to infer the ML $18 \mathrm{~S}$ phylogeny. A Tamura-Nei model (Tamura and Nei, 1993) was used for the NJ phylogeny. For both methods, bootstrap values were estimated using 1000 replicates. The ML topology was used for all phylogenetic trees shown in this paper, which were constructed using MEGA5 (Tamura et al., 2011).

For some Pedinellales species, only a portion of the $18 \mathrm{~S}$ rRNA gene is available in literature. Therefore, we aligned only the corresponding portion of our Pedinellales sequences and inferred a partial $18 \mathrm{~S}$ phylogeny. The tree was constructed from an alignment of 37 sequences from Pedinellales as well as other Heterokontophyta based on 434 unambiguously aligned positions.

Since all the 24 ITS sequences obtained for Arctic Micromonas (Mamiellophyceae) were identical, only three of them were considered for the phylogenetic analysis. These sequences were aligned with sequences from other Mamiellophyceae strains from our study as well as from previous works (Slapeta et al., 2006), for a total of 18 sequences. 425 unambiguously aligned positions were used and the phylogenetic tree topology was inferred by the ML method using a Kimura 2-parameter model (Kimura, 1980), and a discrete gamma distribution (5 categories $(+\mathrm{G}$, parameter $=0.4993)$ ) was used to model evolutionary rates. $\mathrm{NJ}$ method and bootstrap values were calculated as described above.

The $28 \mathrm{~S}$ rRNA gene sequences from the two dinoflagellate strains (RCC2013 and FT56.6 PG8) isolated from the MALINA cruise were aligned with 33 reference sequences from other dinoflagellates, and 542 unambiguously aligned positions were considered. Different models of DNA substitution were estimated and a GTR model with a discrete gamma distribution $(5$ categories $(+\mathrm{G}$, parameter $=0.59)$ ) was used to infer ML phylogeny, whereas NJ phylogeny and boostrap values were calculated as described above.

\subsection{Microscopy}

At least one strain per genotype was observed using light microscopy. Cells were collected during the exponential growth phase and observed using an Olympus BX51 microscope (Olympus, Hamburg, Germany) with a 100X objective using differential interference contrast (DIC). Cells were imaged with a SPOT RT-slider digital camera (Diagnostics Instruments, Sterling Heights, MI, USA) either directly or after fixation with $0.25 \%$ acidic lugol solution (0.6 M KI, $0.39 \mathrm{M}$ crystalline iodine and $1.6 \mathrm{M} \mathrm{CH}_{3} \mathrm{COOH}$, Sigma Aldrich, Saint-Quentin, France). Micrographs are available at http://www.sb-roscoff.fr/Phyto/RCC for a large set of strains. 
Strain RCC2013 was also prepared for scanning electron microscopy (SEM), using the method described by Moestrup et al. (2009a). Cells were fixed in a mixture of $600 \mu \mathrm{l} 2 \%$ $\mathrm{OsO}_{4}$ and a $200 \mu \mathrm{l}$ saturated $\mathrm{HgCl}_{2}$ solution. Samples were placed on 3- $\mu \mathrm{m}$-pore size Nuclepore (Pleasanton, CA, USA) polycarbonate filters, washed with distilled water, dehydrated in an ethanol series $(25 \%, 50 \%, 75 \%, 95 \%, 100 \%)$ and critical point dried. The filters were mounted on stubs, sputter coated with gold and examined with a JEOL JSM-6500F SEM (JEOL-USA Inc., Peabody, MA, USA).

\section{Results}

Using a range of techniques we isolated 104 strains of photosynthetic flagellates from different Arctic regions. Ninety-three strains have been deposited to the Roscoff Culture Collection (RCC), whereas the others have been lost or discarded subsequently. Complete information is available at http://www.sb-roscoff.fr/Phyto/RCC. After a preliminary phylogenetic analysis, the strains were grouped into 21 genotypes for which the full $18 \mathrm{~S}$ rRNA gene was subsequently sequenced.

We isolated 63 Chlorophyta strains, 41 of which belonged to Arctic Micromonas, and 41 strains affiliated to Alveolata, Cryptophyta, Haptophyta, and Heterokontophyta (Table 2).

\subsection{Chlorophyta, Mamiellophyceae}

Arctic Micromonas. Fourty-one strains belong to Arctic Micromonas and were isolated from the northern stations of leg $1 \mathrm{~b}$ and from 10 stations of leg $2 \mathrm{~b}$ (Table 2, Supplement, Table S1) at different depths.

Cells are spherical, $2 \mu \mathrm{m}$ in diameter with a flagellum about $5 \mu \mathrm{m}$ long (Fig. 1.1). Consistent with a previous study (Lovejoy et al., 2007), the full 18 S rRNA gene sequences from our Micromonas strains RCC2306 and RCC2308 group with other Arctic sequences forming a sub-clade (94\% ML bootstrap support) within clade B sensu Guillou et al. (2004). This sub-clade is distinct from Micromonas sequences recovered from tropical and temperate waters (Fig. 2, Chlorophyta, Mamiellophyceae). Although our strains have been isolated from both oligotrophic and mesotrophic waters, ITS sequences were identical for all strains, as well as identical to previously published ITS sequences of Arctic Micromonas (CCMP2099, Fig. 3).

Bathycoccus prasinos. We isolated one strain representative from another picoplanktonic Mamiellophyceae, $B$. prasinos. Unfortunately, this strain was subsequently lost. This strain shares $99.8 \% 18 \mathrm{~S}$ rRNA and $99.5 \%$ ITS rRNA gene sequence identity with $B$. prasinos CCAP K-0417 isolated from the Gulf of Naples.

In contrast to Micromonas, the genus Bathycoccus is genetically homogeneous with very little sequence divergence (Guillou et al., 2004; Worden, 2006), and our strain was genetically identical to several strains collected from different oceans. B. prasinos has been previously shown to occur in the Beaufort Sea (Lovejoy et al., 2007), and it was recovered by T-RFLP during the MALINA cruise at only four stations (Balzano et al., 2012), suggesting a marginal contribution to summer photosynthetic picoeukaryotes.

Undescribed Mamiellaceae. From two stations in the Bering Sea, we isolated three other strains of Mamiellophyceae. Cells from these strains are hemispherical, $4 \mu \mathrm{m}$ wide, and possess a long $(15 \mu \mathrm{m})$ flagellum and a second very short $(1 \mu \mathrm{m})$ one (Fig. 1.2-1.4). A very pale reddish eyespot and a pyrenoid-like inflated body are also visible. These morphological features correspond to those typical of Mantoniella squamata, although electron microscopy is required for the identification of this species (Moestrup, 1990). The full 18 S rRNA gene sequences from RCC 2285 and RCC2288 cluster with two environmental sequences, from MALINA and the Baltic Sea, respectively (Fig. 2, Chlorophyta, Mamiellophyceae), forming a very robust (100\% bootstrap support, for both ML and NJ) clade distinct from the most closely related genera (Micromonas and Mantoniella). ITS phylogeny confirms this finding, although the branch grouping RCC2285, RCC2288, and RCC2497 is less well supported (71\% bootstrap) in ML (Fig. 3). Both $18 \mathrm{~S}$ rRNA and ITS phylogeny indicate that our strains fall within the family Mamiellaceae but probably belong to a new genus (Figs. 2-3). Detailed electron microscopy of the cell ultrastructure, the flagellar hair, and body scales would be necessary to confirm this.

\subsection{Other Chlorophyta}

Besides Mamiellophyceae, we isolated 17 other Chlorophyta strains belonging to the genera Nephroselmis, Chlamydomonas, Carteria, and Pyramimonas.

Nephroselmis. Three strains (RCC2490, RCC2498, and RCC2499) were isolated from the Bering Strait, with cells 3 to $5 \mu \mathrm{m}$ long (Fig. 1.5), pear-shaped with two unequal flagella (http://www.sb-roscoff.fr/Phyto/RCC, RCC2498). Based on the $18 \mathrm{~S}$ rRNA gene sequence, these strains belong to the same genotype. They cluster together $(100 \% \mathrm{ML}$ and NJ bootstrap support) with sequences from $N$. pyriformis recovered from different oceanic regions and separate from other Nephroselmis species (Fig. 2, Chlorophyta, Nephroselmidophyceae). Since the $18 \mathrm{~S}$ rRNA gene appears to be a good molecular marker for identifying Nephroselmis up to the species level (Nakayama et al., 2007), our data suggest that our strains belong to $N$. pyriformis, a cosmopolitan species occurring in temperate, tropical, but also western Greenland polar waters (Moestrup, 1983; Lovejoy et al., 2002; Nakayama et al., 2007).

Chlamydomonas. We found two genotypes belonging to this genus. Cells from strain RCC2488 (referred as Chlamydomonas sp. I) are approximately $10 \mu \mathrm{m}$ long and $5 \mu \mathrm{m}$ wide, with an ovoid shape (Fig. 1.6). Their $18 \mathrm{~S}$ rRNA 
gene sequences is identical to that of the freshwater species C. raudensis (Fig. 2, Chlorophyta, Chlorophyceae), which has been previously reported in an Antarctic lake (Pocock et al., 2004). Chlamydomonas sp. I clusters with $C$. raudensis and $C$. parkerae within the Moewusii clade sensu Pocock (Pocock et al., 2004).

Strains RCC2041 and RCC2512 (corresponding to Chlamydomonas sp. II) are larger in size (approximately $20 \mu \mathrm{m}$ long and $10 \mu \mathrm{m}$ wide), with a reddish, clearly distinguishable eyespot and a basal pyrenoid (Fig. 1.7). An apical papilla is also slightly visible. Chlamydomonas sp. II clusters with freshwater strains, especially from polar waters, 5 forming a well (100\% ML and NJ bootstrap) supported clade (Fig. 3, Chlorophyta, Chlorophyceae), and falls into the Polytoma clade (Pocock et al., 2004).

Carteria. Strain RCC2487 belongs to the genus Carteria. Cells are almost spherical, approximately $30 \mu \mathrm{m}$ long and $25 \mu \mathrm{m}$ wide (Fig. 1.8). Our strain is genetically affiliated with CCMP1189 isolated from Arctic waters, and both strains group with $C$. radiosa, $C$. obtusa, and a freshwater Carteria sp., forming a very robust $(100 \% \mathrm{ML}$ and NJ bootstrap support) clade (Fig. 2) which likely corresponds to the Carteria I clade (Suda et al., 2005). Members from this clade usually occur in temperate water, and to the best of our knowledge this is the first record of an Arctic strain belonging to this clade.

Pyramimonas. Eleven strains, belonging to four distinct genotypes have been isolated. Cells are spherical to pear-like shaped, 5 to $10 \mu \mathrm{m}$ long and 3 to $6 \mu \mathrm{m}$ wide (Fig. 1.9-1.12). A pyrenoid in the middle or apical region of the cell, a chloroplast with three to four lobes, and a lateral reddish eyespot may be visible in light microscopy. Strains from the different genotypes are undistinguishable in light microscopy and a certain degree of morphological variability in terms of shape (spherical to pear-shaped) and presence of eyespot may occur within the same strain.

Pyramimonas is a highly diverse genus comprising four distinct subgenera (Daugbjerg et al., 1994; Moro et al., 2002). The $18 \mathrm{~S}$ rRNA gene sequences of Pyramimonas sp. I (strain RCC2009) and Pyramimonas sp. IV (RCC2500, RCC2501) group with those of $P$. australis and P. parkerae within the subgenus Trichocystis (Fig. 2, Chlorophyta, Pyramimonadales). Pyramimonas sp. II (RCC2009, RCC2015, RCC2047, RCC2048, RCC2295, RCC2296, RCC2297, RCC2502) and Pyramimonas sp. III (RCC1987) cluster with $P$. gelidicola and $P$. disomata within the subgenus Vestigifera. Due to the low 18 S rRNA gene variability of the genus Pyramimonas at an interspecific level (Caron et al., 2009), the different species cannot be discriminated solely by their $18 \mathrm{~S}$ rRNA sequences. Other phylogenetic markers commonly used for Chlorophyta such as $r b c L$ do not resolve Pyramimonas taxonomy either (Suda, 2004), and electron microscopy is required for a detailed identification.

\subsection{Haptophyta, Prymnesiophyceae}

We isolated 4 Prymnesiophyceae strains, affiliated to two genotypes, during leg $1 \mathrm{~b}$.

Haptolina. Strains RCC2299 and RCC2300 were isolated from the NE Pacific (Table 2). Cells are spherical, about $5 \mu \mathrm{m}$ in diameter with two yellow-brown chloroplasts and two flagella (Fig. 1.13). The spines and the haptonema are not visible in light microscopy. The taxonomy of Prymnesiales has been recently revised with the description of the new genus Haptolina and the transfer to this genus of a number of species previously affiliated to Chrysochromulina, including $H$. ericina and $H$. hirta (Edvardsen et al., 2011), which are the two species clustering with RCC2300 (92\% ML bootstrap support, Fig. 2, Prymnesiophyceae). These two species cannot be discriminated using the $18 \mathrm{~S}$ rRNA gene, but other taxonomic markers such as the $28 \mathrm{SrRNA}$ gene could have helped for the identification (Edvardsen et al., 2011). This clade has a sister clade which includes H. fragaria and an environmental sequence from MALINA (Fig. 2, Prymnesiophyceae), and these two clades are well supported and delineate the genus Haptolina as shown previously (Edvardsen et al., 2011).

Imantonia. Strains RCC2298 and RCC2504 contain cells approximately $3 \mu \mathrm{m}$ long, spherical or pear shaped $(3 \mu \mathrm{m}$ long and $2 \mu \mathrm{m}$ wide, Fig. 1.14). Two lateral chloroplasts and two flagella are located in the wider part of the cell. A single species, I. rotunda, has been described for this genus to date. Strain RCC2298 shares 99.8\% 18 S rRNA gene identity with I. rotunda strain ALGO HAP23 (GenBank accession number AM491014), as well as two unidentified Imantonia strains (Fig. 2, Prymnesiophyceae). Representatives of the genus Imantonia have been previously recorded in high latitude (Backe-Hansen and Throndsen, 2002) and temperate (Percopo et al., 2011) waters.

\subsection{Cryptophyta, Cryptophyceae}

Rhodomonas. The eleven Cryptophyceae strains isolated from one NE Pacific and five Beaufort Sea stations belong to the same genotype. Cells are ovoid, approximately $20 \mu \mathrm{m}$ long and $10 \mu \mathrm{m}$ wide, with two greenish-brown chloroplasts and a short furrow extending posteriorly (Fig. 1.15). Cells possess two equal flagella inserting into a ventral furrow. The genus Rhodomonas can be distinguished from the closely related genus Storeatula because the latter lack the furrow (Deane et al., 2002).

The full $18 \mathrm{~S}$ rRNA gene sequence from RCC2020 clusters with $R$. abbreviata (81\% ML bootstrap support, Fig. 2, Cryptophyceae). Genus level phylogeny is not well resolved for Rhodomonas; the RCC2020/R. abbreviata clade branches with other Rhodomonas species but also with other genera such as Rhinomonas, Storeatula, Cryptomonas, and Pyrenomonas (Fig. 2, Cryptophyceae). This confirms previous findings highlighting that Rhodomonas is a 


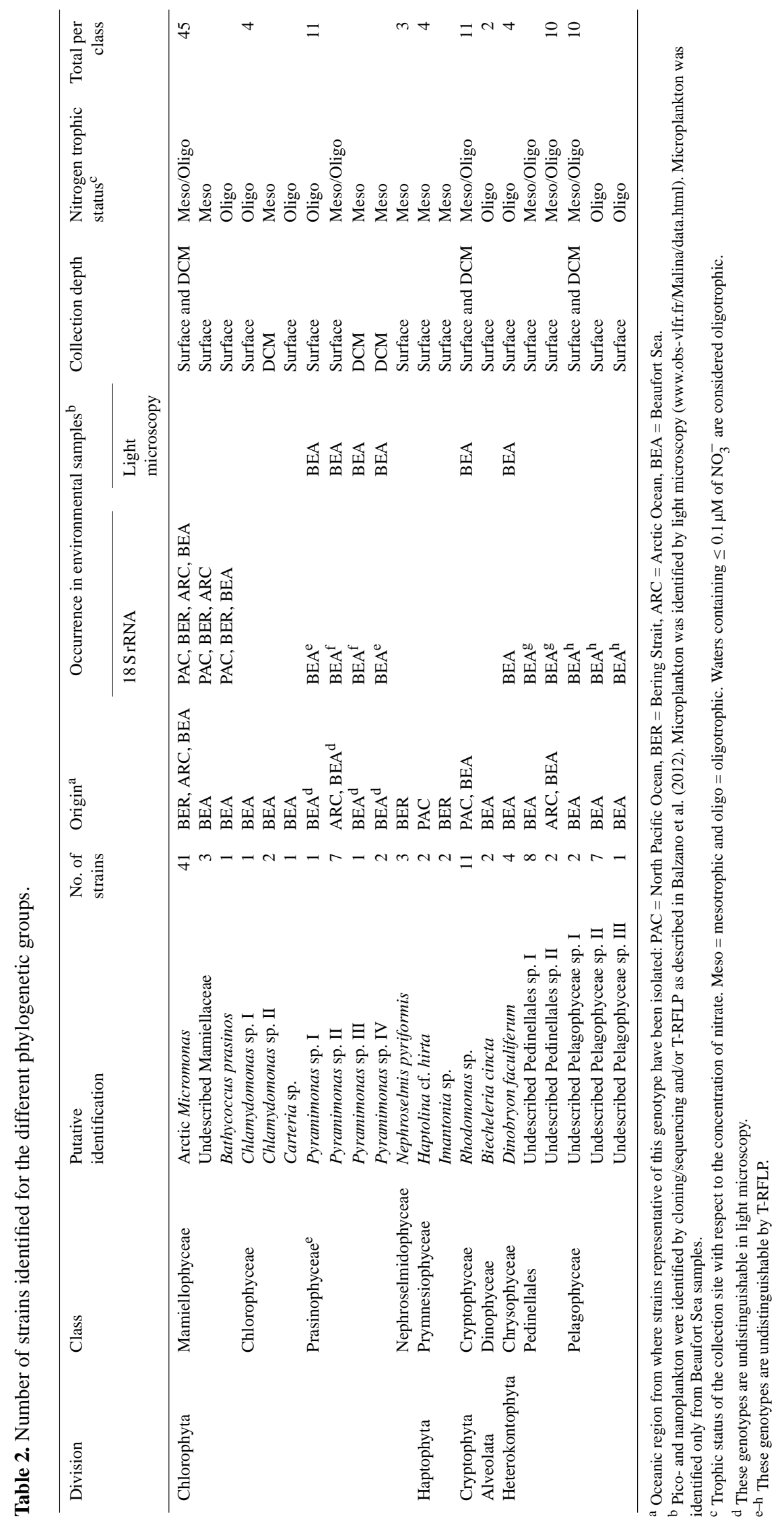




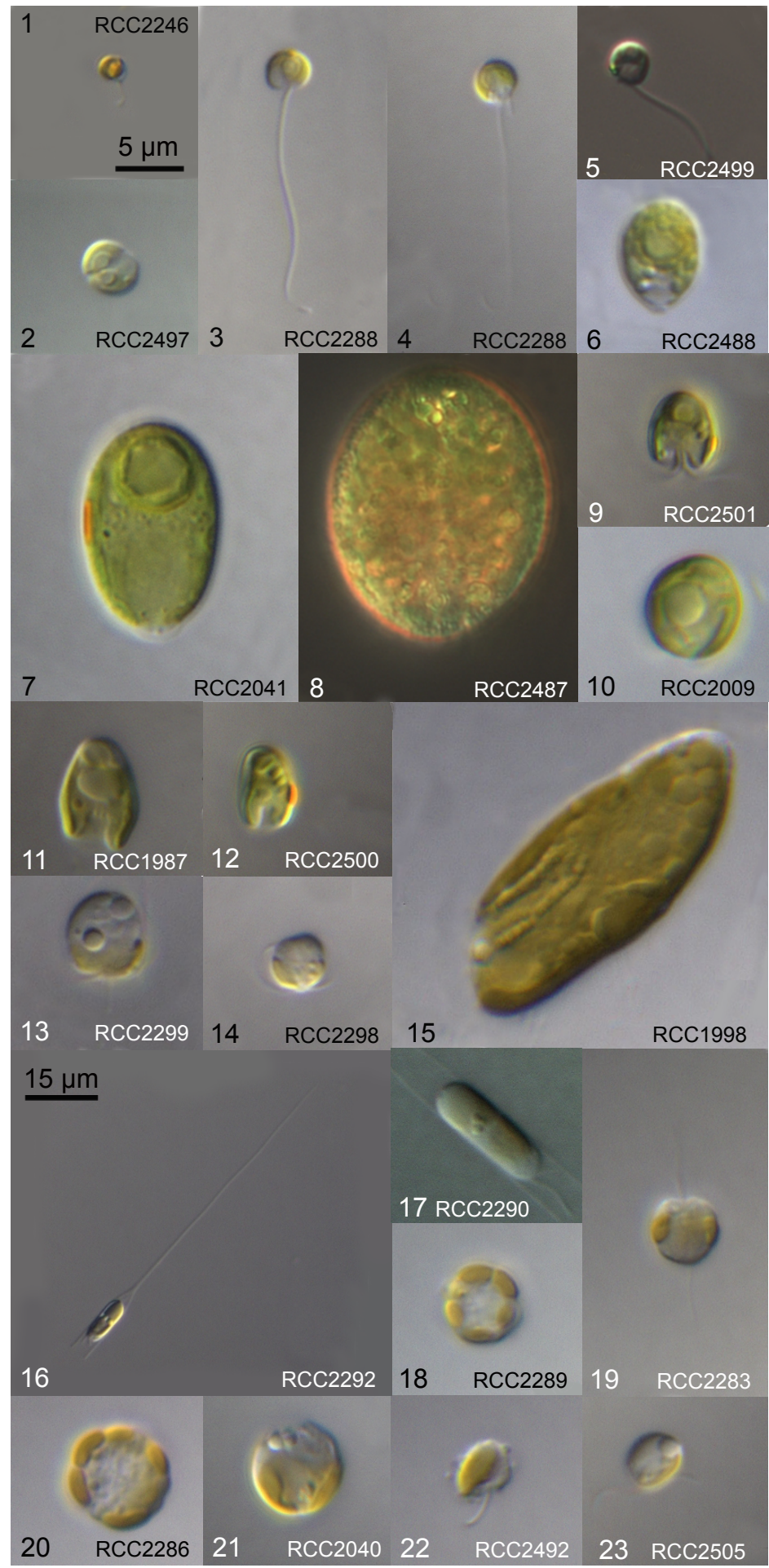

Fig. 1. Microscopy images of a selection of strains isolated during the MALINA cruise. Scale bar is $5 \mu \mathrm{m}$ for all images except for Dinobryon faculiferum (1.16), for which it is $15 \mu \mathrm{m}$. Please note that the images 1.1, 1.3, 1.5, 1.13, 1.18, 1.19, 1.22 and 1.23 include strains that have been photographed after lugol fixation whereas the other images have been obtained on living microorganisms. Mamiellophyceae: (1) Arctic Micromonas strain RCC2246. (2) Undescribed Mamiellaceae strain RCC2497. (3, 4) Undescribed Mamiellaceae strain RCC2288. Cell possesses two unequal flagella. Nephroselmidophyceae: (5) Nephroselmis pyriformis strain RCC2499. Chlorophyceae: (6) Chlamydomonas sp. I strain RCC2488. (7) Chlamydomonas sp. II strain RCC2041. Cell possesses a median red eyespot and a basal pyrenoid. (8) Carteria sp. strain RCC2487. Pyramimonadales: (9) Pyramimonas sp. IV strain RCC2501. (10) Pyramimonas sp. I strain RCC2009. (11) Pyramimonas sp. III strain RCC1987. (12) Pyramimonas sp. IV strain RCC 2500. Note red eyespot. Prymnesiophyceae: (13) Haptolina sp. strain RCC2299. (14) Imantonia sp. strain RCC2298. Cryptophyceae: (15) Rhodomonas sp. strain RCC1998. The furrow is clearly visible. Chrysophyceae: (16) Dinobryon faculiferum strain RCC2292. Cell with lorica. (17) Dinobryon faculiferum RCC2290. Dictyochophyceae: (18) Undescribed Pedinellales sp. I strain RCC2289 in apical view. Six chloroplasts are visible. (19) Undescribed Pedinellales sp. I strain RCC2283 in lateral view. Note the presence of an upward flagellum and a downward stalk. (20) Undescribed Pedinellales sp. II strain RCC2286. Pelagophyceae: (21) Undescribed Pelagophyceae. sp. I strain RCC2040. (22) Undescribed Pelagophyceae sp. II strain RCC2492. (23) Undescribed Pelagophyceae sp. III strain RCC2505. 


\section{Heterokontophyta}

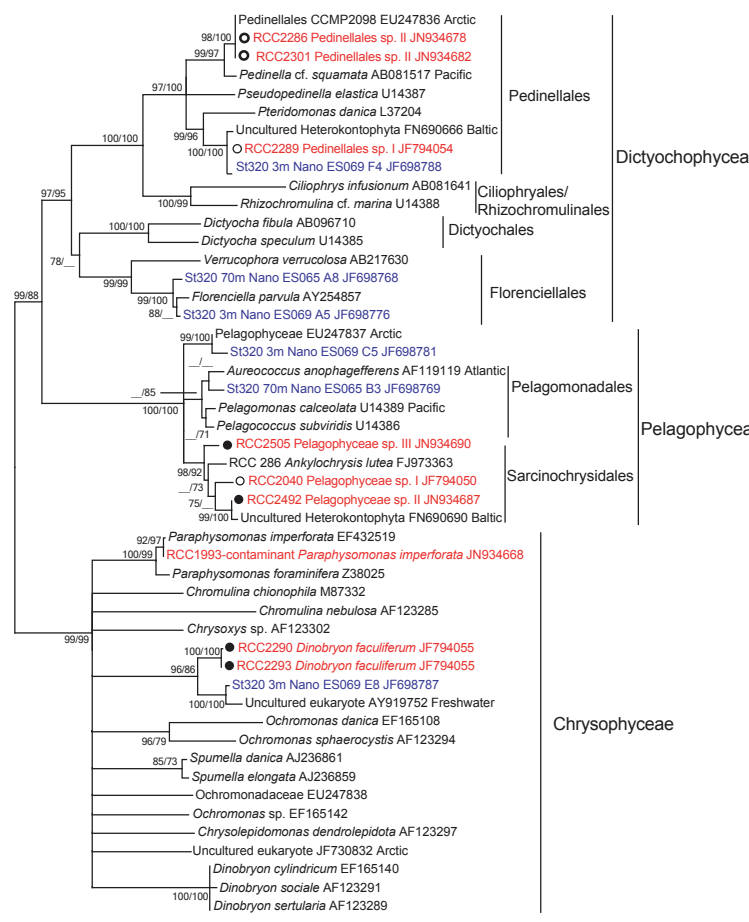

\section{Chlorophyta}

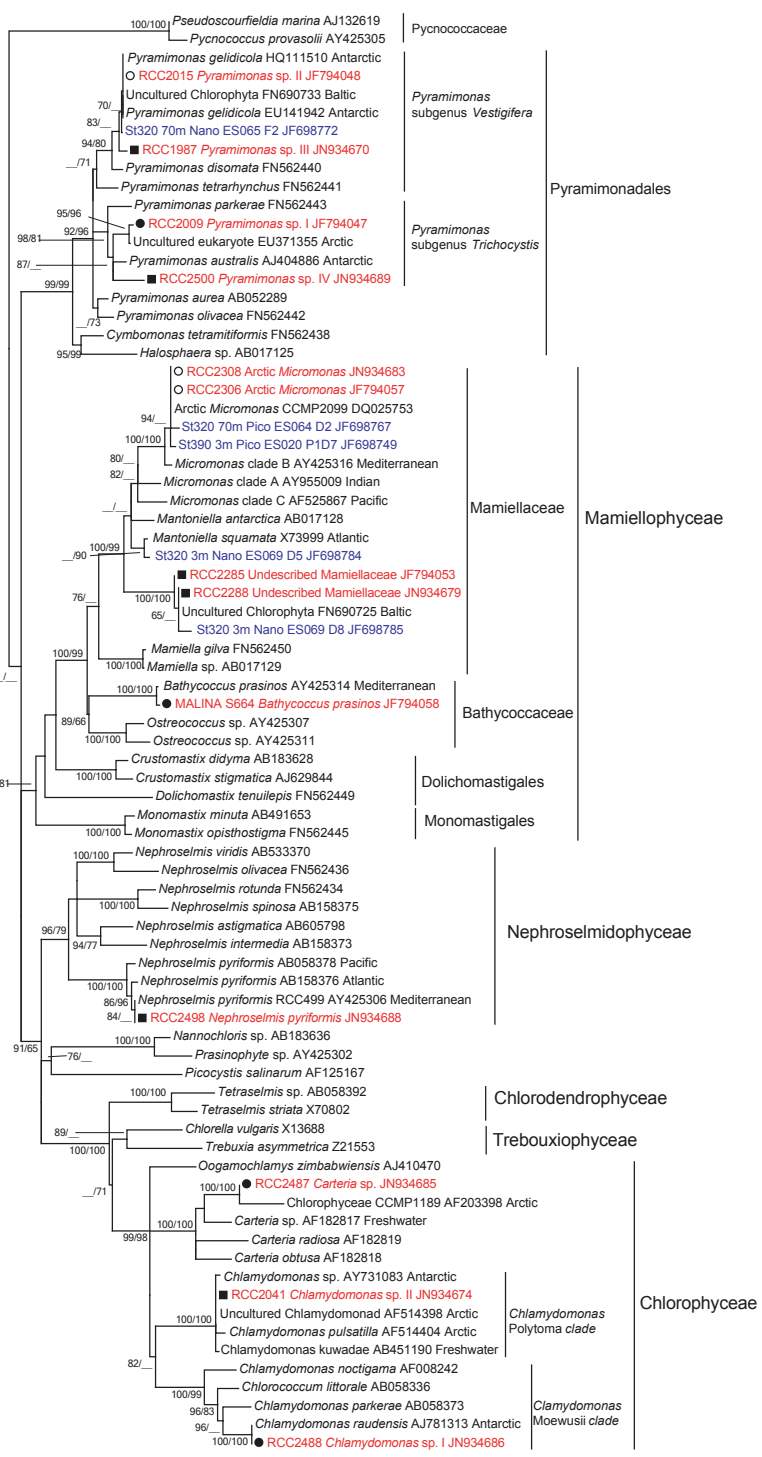

Haptophyta: Prymnesiophyceae

\section{Cryptophyta: Cryptophyceae}

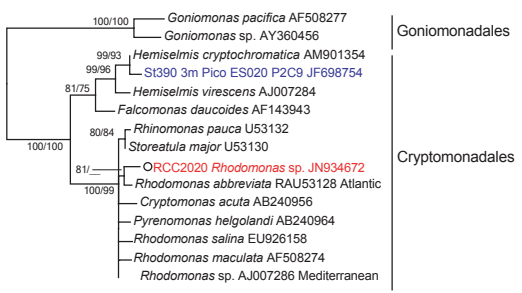

Fig. 2. Full $18 \mathrm{~S}$ rDNA phylogenetic tree including at least one sequence from each genotype found within the strains isolated during the MALINA cruise. The tree has been split into five groups (Heterokontophyta, Chlorophyta, Dinophyceae, Prymnesiophyceae and Crytophyceae); two fungal sequences (Phoma herbarum AY337712 and Sidowia polyspora AY544718) have been used as outgroups and are not shown for clarity. The tree was inferred by maximum likelihood (ML) analysis using MEGA5. 1553 unambiguously aligned positions were considered from an alignment of 180 nucleotide sequences. The strains sequenced in the present study are labelled in red, the environmental sequences recovered during the MALINA cruise (Balzano et al., 2012) are in blue, and other reference sequences from the Genbank are in black. Full circles indicate genotypes isolated from nitrogen depleted waters (surface waters from the leg 2b); full squares, genotypes isolated from mesotrophic waters; and empty circles, genotypes isolated from both conditions. The tree with the highest log likelihood (-26101.3937) is shown. The percentage of trees in which the associated taxa clustered together is shown next to the branches from left (ML, 1000 replicates) to right (NJ, 1000 replicates). "-" indicates that bootstrap values $<70 \%$ were obtained for the corresponding node. Poorly supported clades ( $<50 \%$ bootstrap support) have been removed. A discrete Gamma distribution was used to model evolutionary rate differences among sites $(5$ categories $(+\mathrm{G}$, parameter $=0.4722))$. The rate variation model allowed for some sites to be evolutionarily invariable $((+\mathrm{I}), 27.2360 \%$ sites). The tree is drawn to scale, with branch lengths estimated as the number of substitutions per site. 
polyphyletic genus and its key diagnostic features may represent the characters of the clade (Deane et al., 2002).

\subsection{Alveolata (Dinophyceae)}

We isolated and sequenced from the Beaufort Sea (Table 2) two strains of dinoflagellates (RCC2013 and FT56.6 PG8) belonging to a single genotype. Strain RCC2013 has been observed both in light and electron microscopy, whereas the second strain was lost before these microscopy analyses could be carried out. Cells are almost spherical, approximately $10 \mu \mathrm{m}$ in diameter, with a shallow and descending cingulum, a deep sulcus, and a bright yellow eyespot (Fig. 4.1, arrow). In electron microscopy, four series of plates in the epicone and three in the hypocone are visible (Fig. 4.2 and 4.3), as well as an elongate apical vesicle (EAV, see Moestrup et al., 2009a, for the definition of the EAV, Fig. 4.4 and 4.5).

The morphology of this strain perfectly matches with Woloszynskia cincta Siano, Montresor and Zingone, a species described from the Mediterranean Sea (Siano et al., 2009) and reported also in the Pacific Ocean (Kang et al., 2011). This identification is corroborated by genetic data. The $18 \mathrm{~S}$ rRNA gene sequences from the MALINA strains share $99.9 \%$ identity with the $W$. cincta strain from the Pacific Ocean (Kang et al., 2011), and the 28 S rRNA gene sequences of our strains share $100 \%$ identity with the W. cincta from both the Pacific Ocean and Mediterranean Sea. In both $18 \mathrm{~S}$ and $28 \mathrm{~S}$ rRNA gene sequence phylogenies, $W$. cincta form robust clusters with sequences of the genus Biecheleria (18 S: $100 \%$ bootstrap for both ML and NJ, Fig. 3; $28 \mathrm{~S}: 96 \%$ ML, $100 \%$ NJ bootstrap, Fig. 5), questioning the ascription of $W$. cincta to the genus Woloszynskia.

In recent years, the systematics of the genus Woloszynskia have been revised on the basis of both genetic and morphological data. Many species previously classified as Woloszynskia but morphologically different from the type species of the genus, W. reticulata (Moestrup et al., 2008), have been recombined in four newly described genera: Biecheleria, Borghiella, Jadwigia, and Tovellia (Lindberg et al., 2005; Moestrup et al., 2008, 2009a, b). In addition, three new genera of woloszynskioid dinoflagellates have been erected: Baldinia, Biecheleriopsis, and Pelagodinium (Hansen et al., 2007; Moestrup et al., 2009b; Siano et al., 2010). Morphologically, W. cincta shares with Biecheleria pseudopalustris a posterior invagination and a spiny spherical cyst (Moestrup et al., 2009a; Siano et al., 2009). Biecheleria halophila and B. pseudopalustris have a type E eyespot sensu Moestrup and Daugbjerg (Moestrup and Daugbjerg, 2007). The presence of a type E eyespot was not reported in the original description of $W$. cincta based on the Mediterranean strain (Siano et al., 2009), but the ultrastructural analyses of the Pacific strain (Fig. 15 in Kang et al., 2011), genetically identical to the MALINA and the
Mediterranean strains (Figs. 3 and 5), proved the existence of a type E eyespot in W. cincta (Kang et al., 2011).

On the basis of our new morphological and genetic data and previously provided evidences, we therefore propose the following new combination for W. cincta:

Biecheleria cincta (Siano, Montresor \& Zingone) Siano comb. nov.

Basionym: Woloszynskia cincta Siano, Montresor \& Zingone in Siano et al. (2009, 54, Figs. 35-44).

This dinoflagellate species has a wide distribution since it has been found in tropical (Kang et al., 2011), temperate (Siano et al., 2009) and polar waters (this work).

\subsection{Heterokontophyta}

We isolated a total of 25 strains belonging to the classes Chrysophyceae, Dictyochophyceae, and Pelagophyceae, which grouped into 6 distinct genotypes.

\section{Chrysophyceae}

Dinobryon. Four strains have been morphologically identified as Dinobryon faculiferum. Dinobryon species can be easily identified because cells are surrounded by a cellulose lorica. In RCC2292, RCC2293, and RCC2294 cells are solitary and surrounded by a thin and cylindrical lorica $60-90 \mu \mathrm{m}$ long and $5-10 \mu \mathrm{m}$ wide; this lorica terminates with a long spine (Fig. 1.16-1.17). Within the lorica, cells are ovoid, approximately $10 \mu \mathrm{m}$ long and $5 \mu \mathrm{m}$ wide. These features are typical of D. faculiferum (Throndsen, 1997), which has been frequently observed in Arctic waters (Booth and Horner, 1997; Lovejoy et al., 2002).

Genetically, the three strains (Supplement, Table S1) belong to the same genotype, and the strains RCC2290 and RCC2293 (full 18 S rRNA gene) are grouped together and have a sister clade which includes an environmental sequence from MALINA (Fig. 2, Heterokontophyta, Chrysophyceae). Sequences for $D$. faculiferum as well as for other marine Dinobryon species are not available in Genbank and, surprisingly, sequences from other freshwater species such as $D$. sociale, D. cylindricum, and $D$. sertularia form a clade distinct from that of our strains. Marine species of Dinobryon could group with our sequences and form a separate clade from freshwater Dinobryon species. However the phylogeny of the overall genus is not well resolved (Fig. 2, Heterokontophyta, Chrysophyceae). More sequences from marine species will be needed to better characterise this genus.

\section{Dictyochophyceae}

Pedinellales. We isolated 10 strains from this order belonging to two distinct genotypes (Fig. 2, Heterokontophyta, Dictyochophyceae). Strains from these two genotypes are undistinguishable in light microscopy. Cells are spherical, $5-8 \mu \mathrm{m}$ in diameter. In anterior view, cells are 


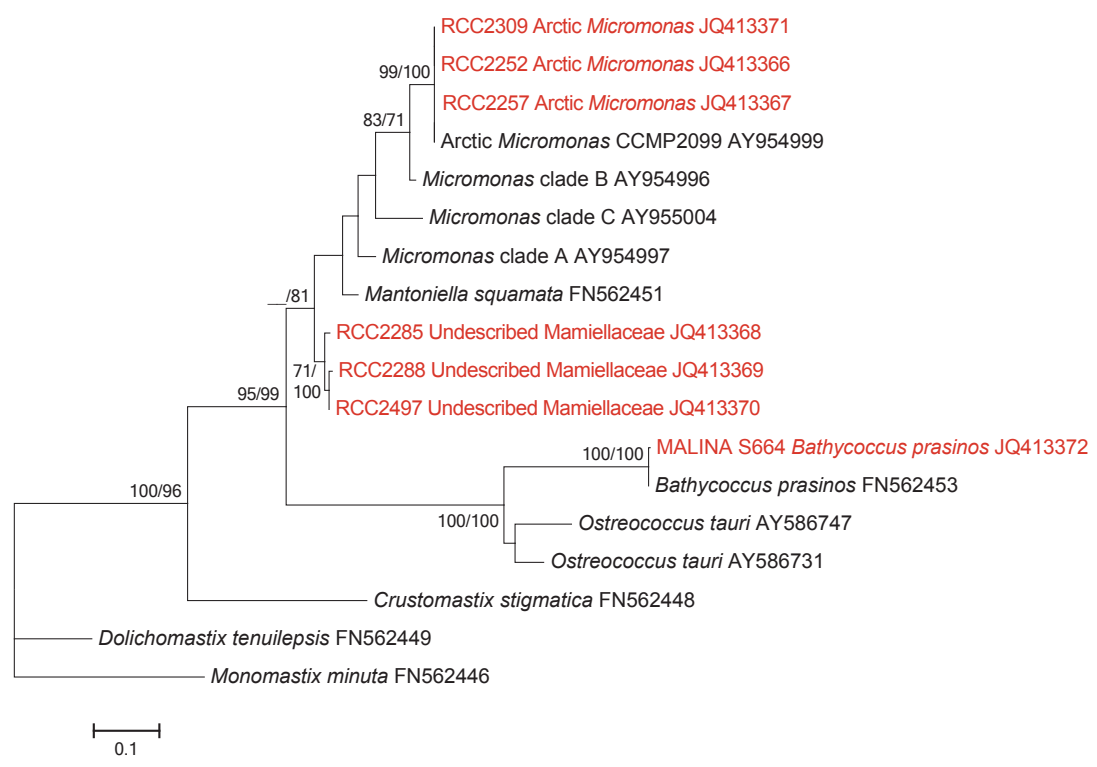

Fig. 3. ITS rRNA based phylogeny of the Mamiellophyceae strains isolated from the Beaufort Sea. The phylogenetic tree was inferred by maximum likelihood (ML) analysis. 425 unambiguously aligned positions were considered from an alignment of 18 sequences. Sequences from MALINA strains are labelled in red. The evolutionary history was inferred by using the maximum likelihood method based on the Kimura 2-parameter model. The tree with the highest log likelihood (-2718.0303) is shown. A discrete Gamma distribution was used to model evolutionary rate differences among sites $(5$ categories $(+\mathrm{G}$, parameter $=0.4993)$ ). The tree is drawn to scale, with branch lengths measured in the number of substitutions per site. The tree was rooted with Monomastix minuta as an outgroup. The tree has been then edited, and ML and NJ bootstrap values have been included as described in Fig. 3. Evolutionary analyses were conducted in MEGA5.

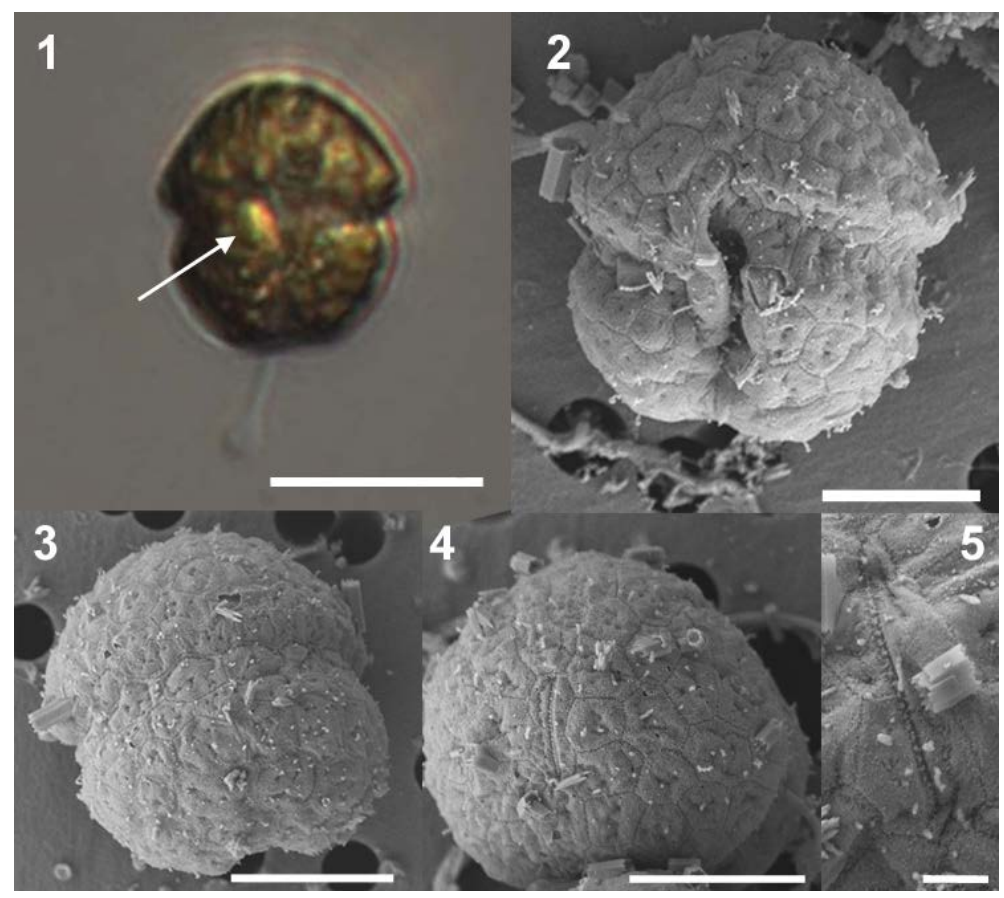

Fig. 4. Light microscopy (LM) and scanning electron microscopy (SEM) micrographs of Biecheleria cincta comb. nov. strain RCC2013. (1) SEM: ventral view, the arrow indicates the eyespot, scale bar $=10 \mu \mathrm{m}$. (2) SEM: ventral view, scale bar $=5 \mu \mathrm{m}$. (3) SEM: dorsal view, scale bar $=5 \mu \mathrm{m}$. (4) SEM: apical view, note the presence of the EAV (elongate apical vesicle), scale bar $=5 \mu \mathrm{m}$. (5) SEM: details of the apical groove, scale bar $=1 \mu \mathrm{m}$. 


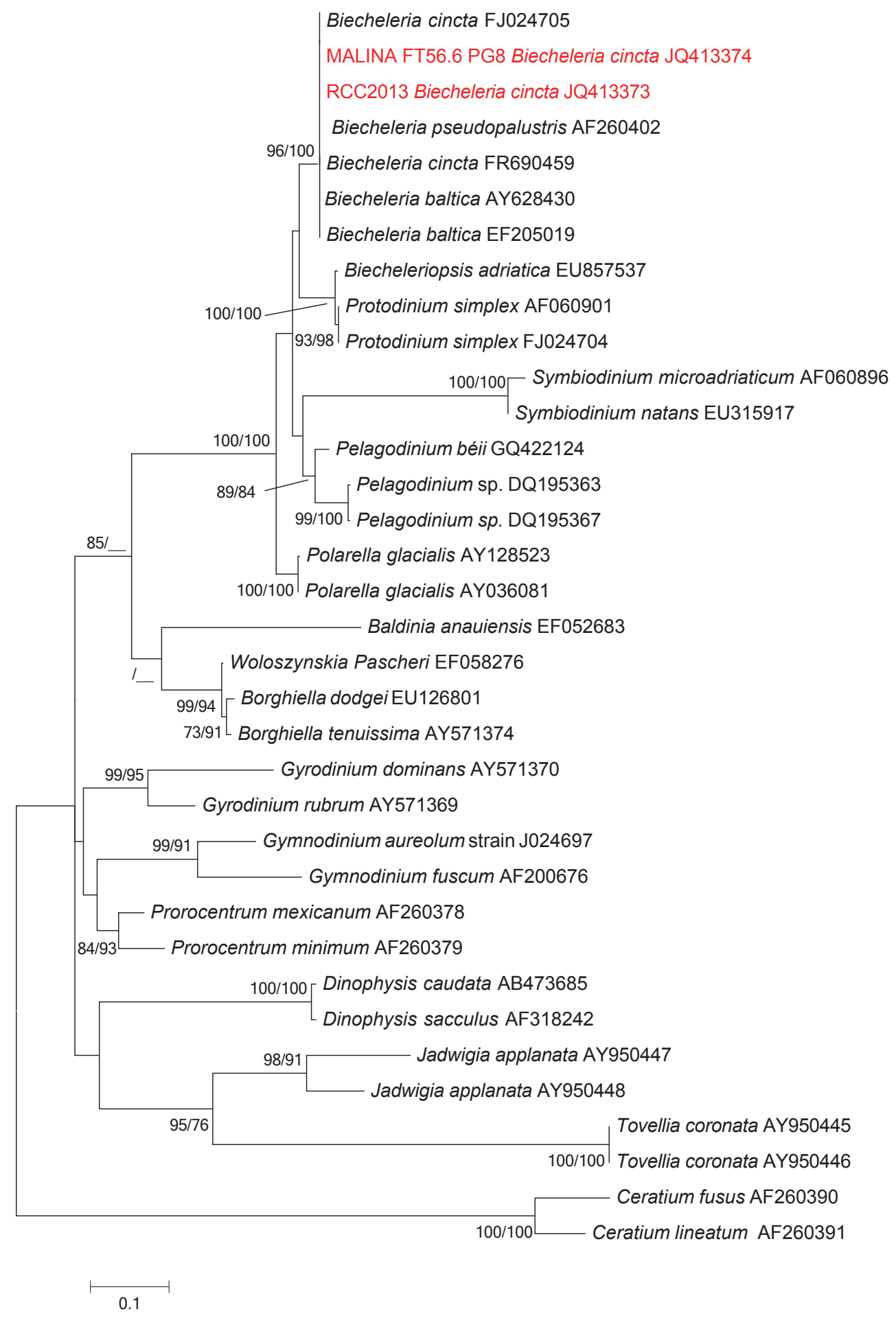

Fig. 5. $28 \mathrm{~S}$ rDNA phylogenetic tree inferred by maximum likelihood (ML) analysis for the dinoflagellate strains isolated during the MALINA cruise. 543 unambiguously aligned positions were considered from an alignment of 35 nucleotide sequences. The strains sequenced in the present study are labelled in red. The tree with the highest log likelihood $(-6075.65)$ is shown. A discrete gamma distribution was used to model evolutionary rate differences among sites $(5$ categories $(+\mathrm{G}$, parameter $=0.63))$. The tree is drawn to scale with branch length measured in the number of substitutions per site. Evolutionary analyses were conducted in MEGA5 (Tamura et al., 2011). The tree was rooted with Ceratium fusus and Ceratium lineatum as outgroups. Bootstrap values $>70 \%$ are shown next to the branches from left (ML, 1000 bootstrap) to right (NJ, 1000 bootstrap). “-” indicates that lower bootstrap values were obtained for the corresponding node. 
radially symmetrical and possess six peripheral chloroplasts (Fig. 1.18 and 1.20). When viewed from the side, a stalk and a flagellum are visible (Fig. 1.19). We are not certain of the genus level identification of our strains because morphological features such as the stalk shape (straight or coiled) and the presence of tentacles, which allow the identification of Pedinellales (Sekiguchi et al., 2003), are not visible.

Genetically, MALINA Pedinellales strains cluster to two distinct groups: the first group includes 7 strains (sp. I) whereas the second group includes two strains (sp. II, Table S1). The full 18 S rRNA gene sequence from RCC2289 (sp. I) clusters with environmental sequences from MALINA and the Baltic Sea $(100 \%$ bootstrap 25 support) and form a sister clade with Pteridomonas danica (Fig. 2, Heterokontophyta, Dictyochophyceae). Partial 18 S rRNA phylogeny indicates that our sequences group with Helicopedinella tricostata (Supplement, Fig. S1), forming a well supported $(94 \%$ and $98 \% \mathrm{ML}$ and $\mathrm{NJ}$, respectively) clade. However, sp. I probably does not belong to the genus Helicopedinella because our strains possess six chloroplasts (Fig. 2), while genus Helicopedinella is defined as containing only three chloroplasts (Sekiguchi et al., 2003).

In contrast, full length sequences from RCC2286 and RCC2301 (sp. II) cluster with the strain CCMP2098 and Pedinella squamata, forming a well supported clade (98\% and $100 \% \mathrm{ML}$ and NJ bootstrap support, respectively) and suggesting that our strains might belong to the genus Pedinella. Partial $18 \mathrm{~S}$ rRNA phylogeny indicates however that our sequences group with $P$. squamata as well as Mesopedinella arctica RCC382 (Supplement, Fig. S1). The attribution of RCC2286 and RCC2301 to the genus Pedinella is thus also uncertain.

Phytoplankton counts from MALINA samples indicate that Pseudopedinella spp. dominate Pedinellales, whereas Pseudopedinella pyriforme and Apedinella spinifera were occasionally present (http://www.obs-vlfr.fr/Malina/ data.html). The partial $18 \mathrm{~S}$ rRNA gene sequences from our strains are distinct from both Apedinella and Pseudopedinella (Supplement, Fig. S1).

Pelagophyceae. Eleven strains affiliated to this class were isolated (Supplement, Table S1) and grouped into three genotypes (Table 2) which cannot be distinguished by light microscopy. Cells are hemispherical or bean shaped in side view, about 5-7 $\mu \mathrm{m}$ long (Fig. 1.21-1.23), and adorned with two lateral flagella and a lateral yellowish-brown chloroplast. These features might correspond to those typical of Ankylochrysis lutea (Honda and Inouye, 1995), and the cells from our strains are similar in size and shape to those of the strain RCC286 identified as A. lutea (http://www. sb-roscoff.fr/Phyto/RCC).

The $18 \mathrm{~S}$ rRNA gene sequences from the three genotypes branch with A. lutea into a well supported clade $(98 \%$ ML, $92 \%$ NJ bootstrap support) distinct from the other 25 Pelagophyceae genera such as Aureococcus, Pelagomonas, and Pelagococcus. Sp. II is closely related to an environmental sequence from Baltic Sea ice (Fig. 2, Heterokontophyta, Pelagophyceae).

\section{Discussion}

\subsection{Isolation and identification success}

The combination of both concentration by TFF and medium enrichment with FCS and single cell pipette isolation proved to be successful for isolating eukaryotic phytoplankton and preventing their contamination by heterotrophic microorganisms. Some of our cultures proved to be non-unialgal and were further purified using single cell FCS. In these cultures, the dominant genotype was initially contaminated either by other phytoplankters (especially the centric diatom Chaetoceros sp.) or by heterotrophs such as uncultured Cercozoa or a Chrysophyceae affiliated to Paraphysomonas imperforata. The latter has a cosmopolitan distribution and is an opportunistic species which often dominates enrichment cultures (Lim et al., 1999).

Several genotypes could not be identified down to the species level. In addition, Dictyochophyceae and Pelagophyceae strains could not be identified at the genus level, and we found a new genus within Mamiellaceae. Whole mount and/or thin section electron microscopy would be required to characterise these genotypes further.

\subsection{Autotrophic microbial diversity revealed using culturing techniques}

Significant diversity occurred within cultured photosynthetic flagellates, and 8 genotypes found here were not detected by T-RFLP or cloning/sequencing of environmental samples sorted by flow cytometry based on their chlorophyll fluorescence, and thus containing only photosynthetic eukaryotes (Table 2). Within these genotypes, Rhodomonas sp. was not targeted during sorting because it contained orange-fluorescing phycoerythrin and therefore did not appear in the T-RFLP data. However, Rhodomonas sp. was observed by light microscopy in environmental samples (Table 2, http://www.obs-vlfr.fr/Malina/data.html) and was previously found in the North Water Polynya off Greenland (Lovejoy et al., 2002). In contrast, the other genotypes are likely to belong to rare species which can be easily cultured. The rarefaction curve indicates that we sampled a very large portion of the community of photosynthetic flagellates during the MALINA leg $2 b$ that could be cultivated under the conditions we used (Supplement, Fig. S2). However, if we had used a larger diversity of media and isolation strategies, we would have probably recovered many other genotypes.

The four Pyramimonas genotypes are undistinguishable by light microscopy and group into two T-RFLP ribotypes (sp. I/sp. IV and sp. II/sp. III). Similarly, the different genotypes found within Pedinelalles and Pelagophyceae 
share the same T-RFLP patterns for the restriction enzymes used by Balzano et al. (2012) and cannot be discriminated by T-RFLP. Therefore, although we isolated several genotypes within the genus Pyramimonas, the order Pedinellales, and the class Pelagophyceae we cannot determine whether all the cultured genotypes were present in the environmental samples analysed in the companion paper (Balzano et al., 2012).

Surprisingly, we found few dinoflagellates among both our strains and environmental samples of nanoplankton (Balzano et al., 2012). However, microscopy counts revealed the presence of several dinoflagellate species during MALINA, although never as dominant taxa. Most of them were larger than $15 \mu \mathrm{m}$ and belonged to the genera Gymnodinium and Gyrodinium (http://www.obs-vlfr.fr/Malina/data.html). Dinoflagellates are an important component in the Arctic (Okolodkov and Dodge, 1996), and they occur during summer in the Chukchi Sea (Booth and Horner, 1997) and the North Water Polynya (Lovejoy et al., 2002). In the Beaufort Sea, however, they seem to occur in autumn (Brugel et al., 2009) rather than in mid summer (Okolodkov, 1999; Sukhanova et al., 2009), which was the period of the MALINA cruise.

\subsection{Culturable phytoplankton in oligotrophic waters}

Interestingly, 8 out of the 21 genotypes found here correspond to strains isolated during leg $2 \mathrm{~b}$ from surface waters which were depleted in inorganic nitrogen (Table 2, Supplement, Table S1). Inorganic nitrogen, which was undetectable in the surface layer during MALINA, has been shown to limit bacterial production (Ortega-Retuerta et al., 2012) and was likely to limit primary production as well. The diversity found in surface waters contrasts with the fact that oligotrophic environments are generally considered to harbour slow growing/hard to cultivate phytoplankton. For example during a similar study in the southeast Pacific, no strain could be isolated from the two most oligotrophic sites (Le Gall et al., 2008). Similarly, cultured microbes contribute very poorly to phytoplankton diversity in other oligotrophic waters such as the eastern Mediterranean Sea (Viprey et al., 2008; Man-Aharonovich et al., 2010), the Sargasso Sea (Not et al., 2007), or the northeast Atlantic Ocean (Jardillier et al., 2010). This suggests that resilient ecotypes adapted to the sub-freezing temperatures and variable salinities observed in the Arctic are more easily culturable than ecotypes from warm and relatively stable temperate or tropical oligotrophic waters.

In contrast, Arctic Prymnesiophyceae from oligotrophic environments appear hard to be brought in culture. The strains isolated in this study derive from mesotrophic environments of the NE Pacific or the Bering Strait, and we could not culture any Prymnesiophyceae from the Beaufort Sea, although they occurred in environmental samples. In particular, 4 operational taxonomic units (OTUs) affiliated to the genus Chrysochromulina were observed by T-RFLP and cloning/sequencing in both surface and DCM samples during MALINA (Balzano et al., 2012). Microscopy counts also revealed the presence of Chrysochromulina spp. throughout the Beaufort Sea (http://www.obs-vlfr.fr/Malina/data.html).

\subsection{Low diversity of photosynthetic picoplankton}

Arctic Micromonas and B. prasinos were the only taxa of picoplanktonic size recovered during this study. Imantonia rotunda has been previously reported to be $<2 \mu \mathrm{m}$ (Vaulot et al., 2008), but our strains of Imantonia sp. had a larger size (Fig. 1.14). In contrast, during a similar study carried out in another oligotrophic system, the southeast Pacific Ocean, photosynthetic picoplankton was more diverse (Shi et al., 2009) and picoplanktonic strains belonging to several different lineages were successfully isolated and cultured (Le Gall et al., 2008). A higher diversity of total photosynthetic picoeukaryotes has also been reported in other warmer oligotrophic regions such as the Sargasso Sea (Not et al., 2007), the Mediterranean Sea (Viprey et al., 2008), and the northeast Atlantic Ocean (Jardillier et al., 2010).

The photosynthetic picoplankton community in the Arctic consists almost uniquely of a single Arctic Micromonas ecotype, which occurs throughout the Beaufort Sea. Since all our strains share identical $18 \mathrm{~S}$ rRNA and ITS sequences, Arctic Micromonas populations are likely to be highly homogeneous despite the fact that they are present in both surface nitrate-depleted waters and deeper, colder, saltier, nitrate-replete waters. The ubiquity and dominance within picoplankton of Arctic Micromonas throughout the Beaufort Sea (Balzano et al., 2012) indicates that it can grow or at least survive throughout a wide range of salinities (14 to $32 \mathrm{psu}$ ) and temperatures $\left(1\right.$ to $\left.7^{\circ} \mathrm{C}\right)$, as well as under both nitrate-depleted $(<3 \mathrm{nM})$ and nitrate-replete (up to $6.7 \mu \mathrm{M}$ ) conditions.

Nitrate-depleted conditions in general promote the growth of picoplankton over larger cells because of the lower surface to volume ratio, and accordingly, photosynthetic picoplankton was generally more abundant than nanoplankton in surface waters of the Beaufort Sea during the MALINA cruise (http://tinyurl.com/67wn5qc). Arctic Micromonas is able to survive cold waters and long dark winters (Sherr et al., 2003; Lovejoy et al., 2007), this makes it prevail over other photosynthetic picoplankters under Arctic conditions. In the Beaufort Sea, coastal waters may reach higher $\left(7^{\circ} \mathrm{C}\right)$ temperatures during summer, but they remain throughout the whole year surrounded by colder waters, and the transport and survival of phytoplankton species from temperate waters is thus highly unlikely. In contrast, the Norwegian and Barents Seas are in close contact with temperate waters from the Atlantic Ocean. The photosynthetic picoplankton is more diverse there; Arctic Micromonas occurs with other Micromonas clades (Foulon et al., 2008), as well as with other Chlorophyta and Haptophyta (Not et al., 2005). 
Consistent with this hypothesis, the higher temperatures which are observed in the NE Pacific and the Bering Strait (Table 1) explain the presence of other picoeukaryotes such as Mamiellophyceae, Chrysophyceae, and unidentified picoeukaryotes which occur along with the Arctic Micromonas (Balzano et al., 2012).

\subsection{Importance of mixotrophic nano- and microplankton strains}

Strains larger than $2 \mu \mathrm{m}$ appear much more diverse than picoplankton strains. Fourteen out of 21 genotypes (Table 2) found here include strains recovered from nitrogen-depleted surface waters and often correspond to genera reported in oligotrophic systems and sometimes shown to be mixotrophic. For example, mixotrophy has been reported for both freshwater (Bird and Kalff, 1986; Domaizon et al., 2003; Kamjunke et al., 2007) and marine (McKenzie et al., 1995) Dinobryon species including D. faculiferum (Unrein et al., 2010). Dinobryon strains were isolated from nitrogen-depleted waters (Table 2), and Dinobryon cells were also observed in surface water as indicated by microscopy counts (http://www.obs-vlfr.fr/Malina/data. html) and T-RFLP (Balzano et al., 2012). Chloroplast containing Pedinellales from the Baltic Sea have been found to ingest bacteria (Piwosz and Pernthaler, 2010). Similarly, $P$. gelidicola, a species which shares $100 \% 18 \mathrm{~S}$ rRNA gene identity with our strains of Pyramimonas sp. II, was also shown to feed on bacteria (Bell and Laybourn-Parry, 2003). B. cincta comb. nov. isolated from Pacific Ocean was observed to ingest several algal preys using a peduncle located between the two flagella (Kang et al., 2011). Some of the strains isolated during this study might thus be mixotrophic, and their ability to assimilate organic carbon could allow their survival and/or growth under the nitrogen-depleted conditions occurring in surface waters of the Beaufort Sea during summer.

\subsection{Arctic, polar, and cosmopolitan species}

Four out of the 21 genotypes found in the present study (Arctic Micromonas, Pyramimonas sp. I, Pyramimonas sp. III and undescribed Pedinellales sp. II) have a strictly Arctic distribution and 7 genotypes have been sequenced for the first time (Carteria sp., Pyramimonas sp. IV, Rhodomonas sp., D. faculiferum and the three Pelagophyceae genotypes). In contrast, the other genotypes have also been reported in other oceans (Table 2). Similarly, environmental sequences from the MALINA cruise include 34 out 46 OTUs which cluster into new or endemic lineages (Balzano et al., 2012) and previous studies also highlight the prevalence of endemic lineages among Arctic environmental clone libraries (Lovejoy et al., 2006; Luo et al., 2009). The proportion of endemic and polar OTUs within our strains may be overestimated because part of the biogeography of most marine microbes is still unknown and many genotypes found here may occur elsewhere. On the other hand, different species may share the same $18 \mathrm{~S}$ rRNA sequence (e.g. within the genera Pyramimonas or Haptolina), and some of our cosmopolitan genotypes may be related to different species with more restricted geographical distribution.

Pyramimonas species occur frequently in polar waters, as they have been previously reported in Arctic environments (Daugbjerg and Moestrup, 1993; Gradinger, 1996) including the Beaufort Sea water column (Olli et al., 2007; Brugel et al., 2009) and ice (Rozanska et al., 2008) as well as the Barents (Rat'kova and Wassmann, 2002) and Laptev Seas (Tuschling et al., 2000). Other Pyramimonas species occur in the Antarctic Ocean (Moro et al., 2002) where some of them were reported to form blooms in Gerlache Strait (Varela et al., 2002) and Omega Bay (McMinn et al., 2000). Some Pyramimonas species appear to be adapted to the salinity changes typically occurring in the Beaufort Sea, as they were previously found under the ice pack (Gradinger, 1996) and shown to grow across a broad salinity range (Daugbjerg, 2000).

Some of our genotypes might be indeed adapted to salinity changes since sequences from our strains of Pyramimonas sp. II, Pedinellales sp. I, and the undescribed Mamiellaceae as well as from the Beaufort Sea environment al samples (Balzano et al., 2012) match sequences from the Baltic Sea. Although the Baltic Sea is much fresher and far less cold than the Beaufort Sea, both ecosystems undergo seasonal salinity changes and (partial) winter freezing events which may promote the growth of the same species.

The biogeography of Arctic microbes is currently highly debated; similarities between Arctic and Antarctic assemblages have been reported for ice, sediment (Lozupone and Knight, 2005), soil (Chu et al., 2010), snow, air, and freshwater bacteria (Jungblut et al., 2010; Harding et al., 2011), whereas seawater bacteria show a limited dispersal ability suggesting the occurrence of a marine microbial province in the Arctic (Galand et al., 2009, 2010). Similarly, eukaryotic microbes from terrestrial environments of the Arctic may also occur in Antarctic and alpine environments (Harding et al., 2011; Schmidt et al., 2011), whereas marine eukaryotes are less likely to be globally dispersed. Arctic circumpolar isolation occurs, for example, for Arctic Micromonas (Lovejoy et al., 2007), and for the planktonic foraminiferan Neogloboquadrina pachyderma (Darling et al., 2007). However, Arctic barriers have been suggested to weaken, at least for abundant species, because of the ice retreat; increased seawater flows through the Arctic likely imply the dispersion of species from the Pacific to the Atlantic Ocean (Wassman et al., 2011). For example, the Pacific diatom Neodenticula seminae appeared in Labrador Sea for the first time in 1999 (Reid et al., 2007) and Atlantic and Pacific populations of Emiliania huxleyi were found to share similar mitochondrial DNA sequences (Hagino et al., 2011). 
Interestingly, our Chlamydomonas genotypes are cosmopolitan and have a likely freshwater origin since they match sequences from freshwater environments (Fig. 2, Chlorophyta, Chlorophyceae). Our strains have been indeed isolated from Stations 670 and 680 (Table 1), which are located near the main outlets of the Mackenzie River. A previous study already found a high similarity between the Antarctic Chlamydomonas raudensis and an Arctic Chlamydomonas sp. (De Wever et al., 2009), which are both closely related to Chlamydomonas sp. I. Similarly, the freshwater flagellate Spumella comprises three globally distributed clades, one of which has been frequently found in Antarctic waters (Nolte et al., 2010).

Arctic Micromonas, undescribed Mamiellaceae, B. prasinos, and Rhodomonas sp. were found in both the NE Pacific and the Beaufort Sea (Table 2). In contrast, Haptolina sp., Imantonia sp., and $N$. pyriformis only occurred in the NE Pacific and/or the Bering Strait and did not appear in the Chuckchi and Beaufort Seas. The other 14 OTUs were found only in the Beaufort Sea (Table 2). Similarly, planktonic foraminifera from the Beaufort Sea were found to be phylogenetically different from those occurring in the North Pacific and rather related to North Atlantic foraminifera (Darling et al., 2007), suggesting that the Bering Strait may act as a barrier to microbial dispersion.

\section{Conclusions}

The combination of culture-dependent (this study) and culture-independent (Balzano et al., 2012) techniques provided useful insights on phytoplankton diversity in the Beaufort Sea. Photosynthetic picoplankton was almost exclusively represented by highly homogeneous populations of Arctic Micromonas which occurred over a range of temperature, salinity, nutrient and light conditions. The high diversity found for surface nanoplankton and the known ability for some of these species to feed on bacteria suggest that their presence in oligotrophic waters could be supported by a mixotrophic carbon assimilation mode.

\section{Supplementary material related to this article is available online at: http://www.biogeosciences.net/9/ 4553/2012/bg-9-4553-2012-supplement.pdf.}

Acknowledgements. We thank all participants to the MALINA cruise for their help, especially M. Babin who coordinated the project and all CCGS Amundsen crew members. Financial support for this work was provided by the following programs: JST-CNRS "Phytometagene", ASSEMBLE EU FP7, MACUMBA EU FP7, CPER Souchothèque de Bretagne, ANR MALINA (ANR-08-BLAN-0308). We thank E. M. Bendif for help in phylogenetic analyses, and N. Simon for strain identification.

Edited by: W. Li

\section{References}

Backe-Hansen, P. and Throndsen, J.: Pico- and nanoplankton from the inner Oslofjord, eastern Norway, including description of two new species of Luffisphaera (incertae sedis), Sarsia, 87, 55-63, 2002.

Balzano, S., Marie, D., Gourvil, P., and Vaulot, D.: Summer photosynthetic eukaryotic communities in the Beaufort Sea assessed by T-RFLP from flow cytometry sorted samples, ISME J., 6, 1480-1498, 2012.

Bell, E. M. and Laybourn-Parry, J.: Mixotrophy in the Antarctic phytoflagellate, Pyramimonas gelidicola (Chlorophyta: Prasinophyceae), J. Phycol., 39, 644-649, 2003.

Bird, D. F. and Kalff, J.: Bacterial grazing by planktonic lake algae, Science, 231, 493-495, 1986.

Booth, B. C. and Horner, R. A.: Microalgae on the Arctic Ocean Section, 1994: species abundance and biomass, Deep-Sea Res. Pt. II, 44, 1607-1622, 1997.

Booth, B. C., Lewin, J., and Norris, R. E.: Nanoplankton species predominant in the subarctic Pacific in May and June 1978, Deep-Sea Res., 29, 185-200, 1982.

Brugel, S., Nozais, C., Poulin, M., Tremblay, J. E., Miller, L. A., Simpson, K. G., Gratton, Y., and Demers, S.: Phytoplankton biomass and production in the southeastern Beaufort Sea in autumn 2002 and 2003, Mar. Ecol.-Prog. Ser., 377, 63-77, 2009.

Carmack, E. C. and MacDonald, R. W.: Oceanography of the Canadian shelf of the Beaufort Sea: A setting for marine life, Arctic, 55, 29-45, 2002.

Caron, D. A., Countway, P. D., Savai, P., Gast, R. J., Schnetzer, A., Moorthi, S. D., Dennett, M. R., Moran, D. M., and Jones, A. C.: Defining DNA-based Operational Taxonomic Units for microbial-eukaryote ecology, Appl. Environ. Microb., 75, 5797-5808, 2009.

Chu, H. Y., Fierer, N., Lauber, C. L., Caporaso, J. G., Knight, R., and Grogan, P.: Soil bacterial diversity in the Arctic is not fundamentally different from that found in other biomes, Environ. Microbiol., 12, 2998-3006, 2010.

Darling, K. F., Kucera, M., and Wade, C. M.: Global molecular phylogeography reveals persistent Arctic circumpolar isolation in a marine planktonic protist, P. Natl. Acad. Sci. USA, 104, 5002-5007, 2007.

Daugbjerg, N.: Pyramimonas tychotreta, sp. nov. (Prasinophyceae), a new marine species from Antarctica: light and electron microscopy of the motile stage and notes on growth rates, J. Phycol., 36, 160-171, 2000.

Daugbjerg, N. and Moestrup, O.: 4 new species of Pyramimonas (Prasinophyceae) from Arctic Canada including a light and 
electron microscopy description of Pyramimonas quadrifolia SP-NOV, Eur. J. Phycol., 28, 3-16, 1993.

Daugbjerg, N., Moestrup, O., and Arctander, P.: Phylogeny of the genus Pyramimonas (Prasinophyceae, Chlorophyta) inferred from the $r b c L$ gene, J. Phycol., 30, 991-999, 1994.

De Wever, A., Leliaert, F., Verleyen, E., Vanormelingen, P., Van der Gucht, K., Hodgson, D. A., Sabbe, K., and Vyverman, W.: Hidden levels of phylodiversity in Antarctic green algae: further evidence for the existence of glacial refugia, P. Roy Soc. B, 276, 3591-3599, 2009.

Deane, J. A., Strachan, I. M., Saunders, G. W., Hill, D. R. A., and McFadden, G. I.: Cryptomonad evolution: Nuclear $18 \mathrm{~S}$ rDNA phylogeny versus cell morphology and pigmentation, J. Phycol., 38, 1236-1244, 2002.

Domaizon, I., Viboud, S., and Fontvieille, D.: Taxon-specific and seasonal variations in flagellates grazing on heterotrophic bacteria in the oligotrophic Lake Annecy - importance of mixotrophy, FEMS Microbiol. Ecol., 46, 317-329, 2003.

Edvardsen, B., Eikrem, W., Throndsen, J., Saez, A. G., Probert, I., and Medlin, L. K.: Ribosomal DNA phylogenies and a morphological revision provide the basis for a revised taxonomy of the Prymnesiales (Haptophyta), Eur. J. Phycol., 46, 1-27, 2011.

Foulon, E., Not, F., Jalabert, F., Cariou, T., Massana, R., and Simon, N.: Ecological niche partitioning in the picoplanktonic green alga Micromonas pusilla: evidence from environmental surveys using phylogenetic probes, Environ. Microbiol., 10, 2433-2443, 2008.

Galand, P. E., Potvin, M., Casamayor, E. O., and Lovejoy, C.: Hydrography shapes bacterial biogeography of the deep Arctic Ocean, Isme J, 4, 564-576, 2010.

Gradinger, R.: Occurrence of an algal bloom under Arctic pack, Mar. Ecol.-Prog. Ser., 131, 301-305, 1996.

Guillard, R. R. L.: Culture of phytoplankton for feeding marine invertebrates, in: Culture of marine invertebrate animals, edited by: Smith, W. L. and Chanley, M. H., Plenum Book Publication Corporation, New York, 29-60, 1975.

Guillou, L., Eikrem, W., Chrétiennot-Dinet, M. J., Le Gall, F., Massana, R., Romari, K., Pedrós-Alió, C., and Vaulot, D.: Diversity of picoplanktonic prasinophytes assessed by direct nuclear SSU rDNA sequencing of environmental samples and novel isolates retrieved from oceanic and coastal marine ecosystems, Protist, 155, 193-214, 2004.

Hagino, K., Bendif, E., Young, J. R., Kogame, K., Probert, I., Takano, Y., Horiguchi, T., de Vargas, C., and Okada, H.: New evidence for morphological and genetic variation in the cosmopolitan coccolithophore Emiliania huxleyi (Prymnesiophyceae) from the coxlb-atp4 genes, J. Phycol., 47, 1164-1176, 2011.

Hall, T. A.: BioEdit: a user-friendly biological sequence alignement editor and analysis program for Windows 95/98/NT, Nucl. Acid S., 41, 95-98, 1999.

Hansen, G., Daugbjerg, N., and Henriksen, P.: Baldinia anauniensis gen. et sp. nov.: a "new" dinoflagellate from Lake Tovel, N. Italy, Phycologia, 46, 86-108, 2007.

Harding, T., Jungblut, A. D., Lovejoy, C., and Vincent, W. F.: Microbes in High Arctic snow and implications for the cold biosphere, Appl Environ. Microb., 77, 3234-3243, 2011.

Honda, D. and Inouye, I.: Ultrastructure and reconstruction of the flagellar apparatus architecture in Ankylochrysis lutea
(Chrysophyceae, Sarcinochrysidales), Phycologia, 34, 215-227, 1995.

Jardillier, L., Zubkov, M. V., Pearman, J., and Scanlan, D. J.: Significant $\mathrm{CO}_{2}$ fixation by small prymnesiophytes in the subtropical and tropical northeast Atlantic Ocean, ISME J., 4, 1180-1192, 2010.

Jungblut, A. D., Lovejoy, C., and Vincent, W. F.: Global distribution of cyanobacterial ecotypes in the cold biosphere, ISME J., 4, 191-202, 2010.

Kamjunke, N., Henrichs, T., and Gaedke, U.: Phosphorus gain by bacterivory promotes the mixotrophic flagellate Dinobryon spp. during re-oligotrophication, J. Plankton Res., 29, 39-46, 2007.

Kang, N. S., Jeong, H. J., Du Yoo, Y., Yoon, E. Y., Lee, K. H., Lee, K., and Kim, G.: Mixotrophy in the newly described phototrophic dinoflagellate Woloszynskia cincta from western Korean waters: feeding mechanism, prey species and effect of prey concentration, J. Eukaryot. Microbiol., 58, 152-170, 2011.

Kasai, F., Kawachi, M., Erata, M., Mori, F., Yumoto, K., Sato, M., and Ishimoto, M.: NIES-Collection List of strains, 8th Edition, Jap. J. Phycol., 57, 212-225, 2009.

Keller, M. D., Selvin, R. C., Claus, W., and Guillard, R. R. L.: Media for the culture of oceanic ultraphytoplankton, J. Phycol., 23, 633-638, 1987.

Kimura, M.: A simple method for estimating evolutionary rates of base substitutions through comparative studies of nucleotide sequences, J. Mol. Evol., 16, 111-120, 1980.

Le Gall, F., Rigaut-Jalabert, F., Marie, D., Garczarek, L., Viprey, M., Gobet, A., and Vaulot, D.: Picoplankton diversity in the SouthEast Pacific Ocean from cultures, Biogeosciences, 5, 203-214, doi:10.5194/bg-5-203-2008, 2008.

Lenaers, G., Maroteaux, L., Michot, B., and Herzog, M.: Dinoflagellates in evolution. A molecular phylogenetic analysis of large subunit ribosomal RNA, J. Mol. Evol., 29, 40-51, 1989.

Lepère, C., Demura, M., Kawachi, M., Romac, S., Probert, I., and Vaulot, D.: Whole Genome Amplification (WGA) of marine photosynthetic eukaryote populations, FEMS Microbiol. Ecol., 76, 513-523 2011.

Li, W. K. W.: Annual average abundance of heterotrophic bacteria and Synechococcus in surface ocean waters, Limnol. Oceanogr., 43, 1746-1753, 1998.

Lim, L. E., Dennet, M. R., and Caron, D. A.: The ecology of Paraphysomonas imperforata based on studies employing oligonucleotide probe identification in coastal waters and enrichment cultures, Limnol. Oceanogr., 44, 37-51, 1999.

Lindberg, K., Moestrup, O., and Daugbjerg, N.: Studies on woloszynskioid dinoflagellates - I: Woloszynskia coronata re-examined using light and electron microscopy and partial LSU rDNA sequences, with description of Tovellia gen. nov and Jadwigia gen. nov (Tovelliaceae fam. nov.), Phycologia, 44, 416-440, 2005.

Lovejoy, C. and Potvin, M.: Microbial eukaryotic distribution in a dynamic Beaufort Sea and the Arctic Ocean, J. Plankton Res., 33, 431-444, 2011.

Lovejoy, C., Legendre, L., Martineau, M. J., Bacle, J., and von Quillfeldt, C. H.: Distribution of phytoplankton and other protists in the North Water, Deep-Sea Res. Pt. II, 49, 5027-5047, 2002.

Lovejoy, C., Massana, R., and Pedrós-Alió, C.: Diversity and distribution of marine microbial eukaryotes in the Arctic Ocean and adjacent seas, Appl. Environ. Microb., 72, 3085-3095, 2006. 
Lovejoy, C., Vincent, W. F., Bonilla, S., Roy, S., Martineau, M. J., Terrado, R., Potvin, M., Massana, R., and Pedrós-Alió, C.: Distribution, phylogeny, and growth of cold-adapted picoprasinophytes in arctic seas, J. Phycol., 43, 78-89, 2007.

Lozupone, C. and Knight, R.: UniFrac: a new phylogenetic method for comparing microbial communities, Appl. Environ. Microb., 71, 8228-8235, 2005.

Luo, W., Li, H. R., Cai, M. H., and He, J. F.: Diversity of microbial eukaryotes in Kongsfjorden, Svalbard, Hydrobiologia, 636, 233248, 2009.

Marie, D., Shi, X. L., Rigaut-Jalabert, F. , and Vaulot, D.: Use of flow cytometric sorting to better assess the diversity of small photosynthetic eukaryotes in the English Channel, FEMS Microbiol. Ecol., 72, 165-178, 2010.

Man-Aharonovich, D., Philosof, A., Kirkup, B. C., Le Gall, F., Yogev, T., Berman-Frank, I., Polz, M. F., Vaulot, D., and Béjà, O.: Diversity of active marine picoeukaryotes in the Eastern Mediterranean Sea unveiled using photosystem-II $p s b A$ transcripts, ISME J., 4, 1044-1052, 2010.

McKenzie, C. H, Deibel, D., Paranjape, M. A., and Thompson, R. J.: The marine mixotroph Dinobryon balticum (Chrysophyceae), Phagotrophy and survival in a cold ocean, J. Phycol., 31, 19-24, 1995.

McMinn, A., Bleakley, N., Steinburner, K., Roberts, D., and Trenerry, L.: Effect of permanent sea ice cover and different nutrient regimes on the phytoplankton succession of fjords of the Vestfold Hills Oasis, eastern Antarctica, J. Plankton Res., 22, 287-303, 2000.

Moestrup, O.: Further studies on Nephroselmis and its allies, I: The question of the genus Bipedinomonas, Nord. J. Bot., 3, 609-627, 1983.

Moestrup O.: Scale structure in Mantoniella squamata, with some comments on the phylogeny of the Prasinophyceae (Chlorophyta), Phycologia, 29, 437-442, 1990.

Moestrup, O. and Daugbjerg, N.: On dinoflagellate phylogeny and classification, in: Unravelling the Algae: The Past, Present and Future of Algae Systematics., Vol 75., edited by: Brodie, J. and Lewis, J., CRC Press, Taylor and Francis Group, London, 215230, 2007.

Moestrup, O., Hansen, G., and Daugbjerg, N.: Studies on woloszynskioid dinoflageflates III: on the ultrastructure and phylogeny of Borghiella dodgei gen. et sp nov., a cold-water species from Lake Tovel, N. Italy, and on B. tenuissima comb. nov (syn. Woloszynskia tenuissima), Phycologia, 47, 54-78, 2008.

Moestrup, O., Lindberg, K., and Daugbjerg, N.: Studies on woloszynskioid dinoflagellates IV: The genus Biecheleria gen. nov., Phycol. Res., 57, 203-220, 2009a.

Moestrup, O., Lindberg, K., and Daugbjerg, N.: Studies on woloszynskioid dinoflagellates V: Ultrastructure of Biecheleriopsis gen. nov., with description of Biecheleriopsis adriatica sp. nov., Phycol. Res., 57, 323-323, 2009b.

Moro, I., La Rocca, N., Dalla Valle, L., Moschin, E., Negrisolo, E., and Andreoli, C.: Pyramimonas australis sp. nov (Prasinophyceae, Chlorophyta) from Antarctica: fine structure and molecular phylogeny, Eur. J. Phycol., 37, 103-114, 2002.

Nakayama, T., Suda, S., Kawachi, M., and Inouye, I.: Phylogeny and ultrastructure of Nephroselmis and Pseudoscourfieldia (Chlorophyta), including the description of Nephroselmis an- terostigmatica sp. nov. and a proposal for the Nephroselmidales ord. nov., Phycologia, 46, 680-697, 2007.

Nei, M. and Kumar, S.: Molecular Evolution and Phylogenetics, Oxford University Press, New York, 2000.

Nolte, V., Pandey, R. V., Jost, S., Medinger, R., Ottenwalder, B., Boenigk, J., and Schlotterer, C.: Contrasting seasonal niche separation between rare and abundant taxa conceals the extent of protist diversity, Mol. Ecol., 19, 2908-2915, 2010.

Not, F., Massana, R., Latasa, M., Marie, D., Colson, C., Eikrem, W., Pedrós-Alió, C., Vaulot, D., and Simon, N.: Late summer community composition and abundance of photosynthetic picoeukaryotes in Norwegian and Barents Seas, Limnol. Oceanogr., 50, 1677-1686, 2005.

Not, F., Gausling, R., Azam, F., Heidelberg, J. F., and Worden, A. Z.: Vertical distribution of picoeukaryotic diversity in the Sargasso Sea, Environ. Microbiol., 9, 1233-1252, 2007.

Okolodkov, Y. B.: Species range types of recent marine dinoflagellates recorded from the Arctic, Grana, 38, 162-169, 1999.

Okolodkov, Y. B. and Dodge, J. D.: Biodiversity and biogeography of planktonic dinoflagellates in the Arctic Ocean, J. Exp. Mar. Biol. Ecol., 202, 19-27, 1996.

Olli, K., Wassmann, P., Reigstad, M., Ratkova, T. N., Arashkevich, E., Pasternak, A., Matrai, P. A., Knulst, J., Tranvik, L., Klais, R., and Jacobsen, A.: The fate of production in the central Arctic Ocean - Top-down regulation by zooplankton expatriates?, Prog. Oceanogr., 72, 84-113, 2007.

Ortega-Retuerta, E., Jeffrey, W. H., Ghiglione, J. F., and Joux, F.: Evidence of heterotrophic prokaryotic activity limitation by nitrogen in the Western Arctic Ocean during summer, Polar Biol., 35, 785-794, 2012.

Percopo, I., Siano, R., Cerino, F., Sarno, D., and Zingone, A.: Phytoplankton diversity during the spring bloom in the northwestern Mediterranean Sea. Bot., Marina, 54, 243-267, 2011.

Piwosz, K. and Pernthaler, J.: Seasonal population dynamics and trophic role of planktonic nanoflagellates in coastal surface waters of the Southern Baltic Sea, Environ. Microbiol., 12, 364-377, 2010.

Pocock, T., Lachance, M. A., Proschold, T., Priscu, J. C., Kim, S. S., and Huner, N. P. A.: Identification of a psychrophilic green alga from Lake Bonney Antarctica: Chlamydomonas raudensis Ettl. (UWO 241) Chlorophyceae, J. Phycol., 40, 1138-1148, 2004.

Rat'kova, T. N. and Wassmann, P.: Seasonal variation and spatial distribution of phyto- and protozooplankton in the central Barents Sea, J. Mar. Syst., 38, 47-75, 2002.

Reid, P. C., Johns, D. G., Edwards, M., Starr, M., Poulin, M., and Snoeijs, P.: A biological consequence of reducing Arctic ice cover: arrival of the Pacific diatom Neodenticula seminae in the North Atlantic for the first time in 800,000 years, Glob. Change Biol., 13, 1910-1921, 2007.

Rippka, R., Coursin, T., Hess, W., Lichtle, C., Scanlan, D. J., Palinska, K. A., Iteman, I., Partensky, F., Houmard, J., and Herdman, M.: Prochlorococcus marinus Chisholm et al. 1992 subsp pastoris subsp nov strain PCC 9511, the first axenic chlorophyll $a(2) / b(2)$-containing cyanobacterium (Oxyphotobacteria), Int. J. Syst. Evol. Microb., 50, 1833-1847, 2000. 
Rozanska M, Poulin M, and Gosselin M.: Protist entrapment in newly formed sea ice in the Coastal Arctic Ocean, J. Mar. Syst., 74, 887-901, 2008.

Schmidt, S. K., Lynch, R. C., King, A. J., Karki, D., Robeson, M. S., Nagy, L., Williams, M. W., Mitter, M. S., and Freeman, K. R.: Phylogeography of microbial phototrophs in the dry valleys of the high Himalayas and Antarctica, P. R. Soc. B, 278, 702-708, 2011.

Sekiguchi, H., Kawachi, M., Nakayama, T., and Inouye, I.: A taxonomic re-evaluation of the Pedinellales (Dictyochophyceae), based on morphological, behavioural and molecular data, Phycologia, 42, 165-182, 2003.

Sherr, E. B., Sherr, B. F., Wheeler, P. A., and Thompson, K.: Temporal and spatial variation in stocks of autotrophic and heterotrophic microbes in the upper water column of the central Arctic Ocean, Deep-Sea Res. Pt. I, 50, 557-571, 2003.

Shi, X. L., Marie, D., Jardillier, L., Scanlan, D. J., and Vaulot, D.: Groups without cultured representatives dominate eukaryotic picophytoplankton in the oligotrophic South East Pacific Ocean, PLoS One, 4, e7657, doi:10.1371/journal.pone.0007657, 2009.

Siano, R., Kooistra, W., Montresor, M., and Zingone, A.: Unarmoured and thin-walled dinoflagellates from the Gulf of Naples, with the description of Woloszynskia cincta sp nov (Dinophyceae, Suessiales), Phycologia, 48, 44-65, 2009.

Siano, R., Montresor, M., Probert, I., Not, F., and de Vargas, C.: Pelagodinium gen. nov and $P$. beii comb. nov., a dinoflagellate symbiont of planktonic foraminifera, Protist, 161, 385-399, 2010.

Slapeta, J., Lopez-Garcia, P., and Moreira, D.: Global dispersal and ancient cryptic species in the smallest marine eukaryotes, Mol. Biol. Evol., 23, 23-29, 2006.

Suda, S.: Taxonomic characterization of Pyramimonas aurea sp nov (Prasinophyceae, Chlorophyta), Phycologia, 43, 682-692, 2004.

Suda, S., Nozaki, H., and Watanabe, M. M.: Morphology and sexual reproduction of Carteria palmata sp nov belonging to the Carteria group I sensu Lembi (Chlorophyceae, Volvocales), Phycologia, 44, 596-607, 2005.

Sukhanova, I. N., Flint, M. V., Pautova L. A., Stockwell, D. A., Grebmeier, J. M., and Sergeeva, V. M.: Phytoplankton of the western Arctic in the spring and summer of 2002: Structure and seasonal changes, Deep-Sea Res. Pt. II, 56, 1223-1236, 2009.

Tamura, K. and Nei, M.: Estimation of the number of nucleotide substitutions in the control region of mitochondrial DNA in humans and chimpanzees, Mol. Biol. Evol., 10, 512-526, 1993.
Tamura, K., Peterson, D., Peterson, N., Stecher, G., Nei, M., and Kumar, S.: MEGA5: Molecular Evolutionary Genetics Analysis using maximum likelihood, evolutionary distance, and maximum parsimony methods, Mol. Biol. Evol., 28, 2731-2739, 2011.

Throndsen, J.: The Planktonic Marine Flagellates, in: Identifying Marine Phytoplankton, edited by: Tomas, C. R., Academic Press, San Diego, 591-730, 1997.

Tuschling, K., von Juterzenka, K., Okolodkov, Y. B., and Anoshkin, A.: Composition and distribution of the pelagic and sympagic algal assemblages in the Laptev Sea during autumnal freeze-up, J. Plankton Res., 22, 843-864, 2000.

Unrein, F., Gasol, J. M., and Massana, R.: Dinobryon faculiferum (Chrysophyta) in coastal Mediterranean seawater: presence and grazing impact on bacteria, J. Plankton Res., 32, 559-564, 2010.

Varela, M., Fernandez, E., and Serret, P.: Size-fractionated phytoplankton biomass and primary production in the Gerlache and south Bransfield Straits (Antarctic Peninsula) in Austral summer 1995-1996, Deep-Sea Res Pt. II, 49, 749-768, 2002.

Vaulot D., Eikrem W., Viprey M., and Moreau H.: The diversity of small eukaryotic phytoplankton $(\leq 3 \mu \mathrm{m})$ in marine ecosystems. Fems Microbiol. Rev., 32, 795-820, 2008.

Viprey, M., Guillou, L., Férréol, M., and Vaulot, D.: Wide genetic diversity of picoplanktonic green algae (Chloroplastida) in the Mediterranean Sea uncovered by a phylum-biased PCR approach, Environ. Microbiol., 10, 1804-1822, 2008.

Wang, J., Cota, G. F., and Comiso, J. C.: Phytoplankton in the Beaufort and Chukchi Seas: Distribution, dynamics, and environmental forcing, Deep-Sea Res. Pt. II, 52, 3355-3368, 2005.

Wassmann, P., Duarte, C. M., Agusti, S., and Sejr, M. K.: Footprints of climate change in the Arctic marine ecosystem, Glob. Change Biol., 17, 1235-1249, 2011.

White, T., Bruns, T., Lee, S., Taylor, J., Innis, M., Gelfand, D., Shinsky, J.: Amplification and direct sequencing of fungal ribosomal RNA genes for phylogenetics, in: PCR Protocols: A Guide to Methods and Applications, Academic Press, 315-322, 1990.

Worden, A. Z.: Picoeukaryote diversity in coastal waters of the Pacific Ocean, Aquat. Microb. Ecol., 43, 165-175, 2006.

Zhu, F., Massana, R., Not, F., Marie, D., and Vaulot, D.: Mapping of picoeucaryotes in marine ecosystems with quantitative PCR of the 18 S rRNA gene, FEMS Microbiol. Ecol., 52, 79-92, 2005. 